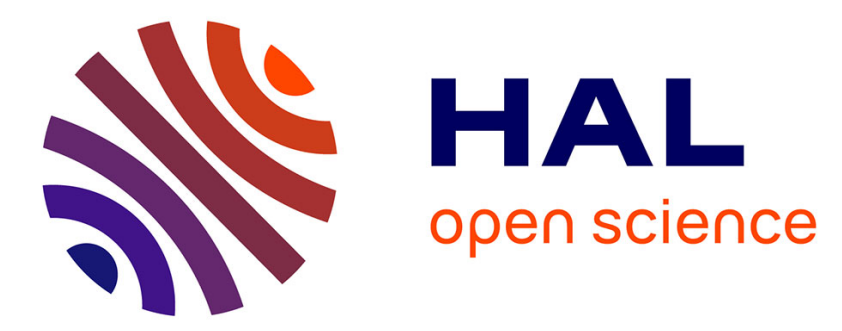

\title{
The genesis of LCT-type granitic pegmatites, as illustrated by lithium isotopes in micas
}

\author{
Sarah Deveaud, Romain Millot, Arnaud Villaros
}

\section{To cite this version:}

Sarah Deveaud, Romain Millot, Arnaud Villaros. The genesis of LCT-type granitic pegmatites, as illustrated by lithium isotopes in micas. Chemical Geology, 2015, 411, pp.97-111. 10.1016/j.chemgeo.2015.06.029 . insu-01172028

\section{HAL Id: insu-01172028 https://hal-insu.archives-ouvertes.fr/insu-01172028}

Submitted on 6 Jul 2015

HAL is a multi-disciplinary open access archive for the deposit and dissemination of scientific research documents, whether they are published or not. The documents may come from teaching and research institutions in France or abroad, or from public or private research centers.
L'archive ouverte pluridisciplinaire HAL, est destinée au dépôt et à la diffusion de documents scientifiques de niveau recherche, publiés ou non, émanant des établissements d'enseignement et de recherche français ou étrangers, des laboratoires publics ou privés. 


\section{Accepted Manuscript}

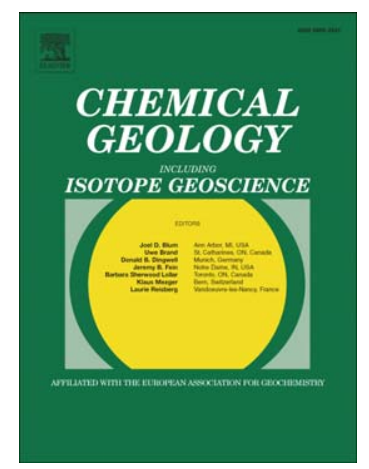

The genesis of LCT-type granitic pegmatites, as illustrated by lithium isotopes in micas

Sarah Deveaud, Romain Millot, Arnaud Villaros

PII:

S0009-2541(15)00317-4

DOI:

doi: 10.1016/j.chemgeo.2015.06.029

Reference: $\quad$ CHEMGE 17625

To appear in: $\quad$ Chemical Geology

Received date: 13 March 2015

Revised date: $\quad 29$ June 2015

Accepted date: $\quad 30$ June 2015

Please cite this article as: Deveaud, Sarah, Millot, Romain, Villaros, Arnaud, The genesis of LCT-type granitic pegmatites, as illustrated by lithium isotopes in micas, Chemical Geology (2015), doi: 10.1016/j.chemgeo.2015.06.029

This is a PDF file of an unedited manuscript that has been accepted for publication. As a service to our customers we are providing this early version of the manuscript. The manuscript will undergo copyediting, typesetting, and review of the resulting proof before it is published in its final form. Please note that during the production process errors may be discovered which could affect the content, and all legal disclaimers that apply to the journal pertain. 
The genesis of LCT-type granitic pegmatites, as illustrated by lithium isotopes in micas

Sarah Deveaud ${ }^{a-c^{*}}$, Romain Millot ${ }^{a-c}$, and Arnaud Villaros ${ }^{a-c}$

${ }^{a}$ BRGM/ISTO, UMR 7327, 3 av. Claude Guillemin, 45060 Orléans, France; s.deveaud@brgm.fr

${ }^{b}$ CNRS/ISTO, UMR 7327, 1 A rue de la Férollerie, 45071 Orléans, France

c Université d'Orléans, ISTO, UMR 7327, 1 A rue de la Férollerie, 45071 Orléans, France

s.deveaud@brgm.fr; r.millot@brgm.fr; arnaudvillaros@gmail.com * Corresponding author

DEVEAUD Sarah

BRGM, DGR/MIN unit, 3 avenue Claude Guillemin, 45060 Orléans, France, (+33) 238 644687

Manuscript submitted to Chemical Geology

June 12, 2015 


\section{ABSTRACT}

Isotopic compositions in the Monts d'Ambazac Pegmatite Field (French Massif Central) exhibit a narrow range of mica $\delta^{7} \mathrm{Li}$ values, ranging from -3.6 to $+3.4 \%$. The value obtained in biotite from the host Saint Sylvestre granite falls within this range $\left(\delta^{7} \mathrm{Li}=-\right.$ $1.5 \%$ ). Lithium concentrations are consistent with the degree of magmatic evolution of each pegmatite type: from $630 \mathrm{ppm}$ in Type II up to $13,500 \mathrm{ppm}$ in the more evolved Type VI pegmatite. Although the rare-element contents e.g., Li, Cs, Ta of the micas are consistent with pegmatite differentiation, $\delta^{7} \mathrm{Li}(\%)$ are firstly, independent of the degree of magmatic differentiation (independent of pegmatite type) and secondly, independent of the content of $\mathrm{Li}$ and other flux-elements such as Be and Cs. Muscovite sampled in pegmatite $\mathrm{V}$ from the Chabannes locality is the only pegmatite to exhibit a $\delta^{7} \mathrm{Li}$ variation from intermediate unit $(-1.7 \%)$ to internal pegmatitic unit $(+3.4 \%)$. The nature of this $\delta^{7} \mathrm{Li}$ variation suggests that there was extensive fractional crystallisation during the pegmatite's consolidation. The independence of $\delta^{7} \mathrm{Li}(\%)$ evolution from the degree of magmatic evolution and the presence of distinct major rare-element bearing phases throughout the pegmatite field tend to confirm that the $\delta^{7} \mathrm{Li}(\%)$ values recorded in mica are inherited from crustal source rocks common to the granite and pegmatite-forming melts. We propose that the distinct pegmatite subtypes (beryl columbite vs lepidolitepetalite subtypes) observed throughout the Monts d'Ambazac Pegmatite Field reflect the diverse contributions of crustal protoliths. The lack of evidence of surrounding alteration combined with the absence of increasing Li-content within the host granite tend to confirm that the $\delta^{7} \mathrm{Li}$ values obtained within this pegmatite field are primary, and that no Li-diffusional process and/or mixing-driven Li-isotope fractionation has overprinted these 
isotopic compositions. In light of these results, the process of partial melting of protoliths enriched in rare-element bearing phases, e.g., mica, garnet, seems to be more responsible for Li-isotope fractionation than Li-diffusion or fractional crystallisation at the temperature of pegmatite consolidation. Finally, we discuss the use of $\mathrm{Li}$ isotopic compositions to identify the most highly evolved pegmatitic systems.

Keywords: granitic pegmatites, micas, Li isotopes, French Massif Central, Monts d'Ambazac Pegmatite Field 


\section{Abbreviations}

MAPF Monts d'Ambazac Pegmatite Field

FMC French Massif Central

SSGC Saint Sylvestre Granitic Complex

AN Angelard Pegmatite

CB Chabannes Pegmatite

CHED Chédeville Pegmatite

MA Margnac I Pegmatite

MA2 Margnac // Pegmatite

MB Mas Barbu Pegmatite

PB Puy de Bos Pegmatite

PB2 Puy de Bos II pegmatite

VH Vilatte Haute Pegmatite 


\section{Introduction}

Granitic pegmatites represent very unusual magmas, which constitute considerable reservoirs of rare elements (Linnen et al., 2012; Dill, 2015). However, the genesis and mineralization of Li-Cs-Ta (LCT) pegmatites (Černý and Ercit, 2005) are still being debated. Processes leading to the genesis of mineralized pegmatite are defined at two distinct geological scales: i) a crustal scale where the pegmatite-forming melt is produced; and ii) the scale of the pegmatite body, where internal physico-chemical processes lead to localized concentrations of rare elements such as $\mathrm{Li}, \mathrm{Be}, \mathrm{Cs}$, and $\mathrm{Ta}$. Most LCT-type pegmatite fields are interpreted as the product of extreme granitic fractionation. Such a magmatic process is defined by fractional crystallisation leading to an increase of rare elements and fluxes in the residual melt with increasing distance from the consolidating parental granitic source (see Cameron et al., 1949; Jahns and Burnham, 1969; London, 2008 and references cited therein, Trueman and Černý, 1982). However, as the connection between a pegmatite and its parental granite cannot always be established, an alternative genetic model based on direct crustal anatexis has been proposed to explain, in certain cases i) the absence of LCT-type pegmatite fields surrounding areas of peraluminous granites (Simmons and Webber, 2008; Simmons et al., 1995); ii) the absence of a geochemical continuum throughout some granitepegmatite systems, e.g., Martins et al., 2012; and iii) the temporal gap existing between a granite and its surrounding pegmatite field, e.g., Melleton et al., 2012. In this alternative model, the rare element contents in the melting source, different melting rates, and tectonic features favor the formation of pegmatitic magma with variable concentrations of rare elements and may trigger the propagation of pegmatitic magma 
through the continental crust. Although these two genetic models are both applied in the literature, the processes leading to rare element concentration in pegmatitic magmas (complete immiscibility of two melts vs constitutional zone refining) are not yet fully understood and need further investigations whose nature is still being debated, e.g., London, 2014a; Thomas and Davidson, 2014.

The diversity of models invoked to explain rare element concentration highlights our lack of understanding of the processes involved in the genesis of LCT-pegmatites (at crustal and pegmatite scales). It is therefore necessary to employ a suitable tracer to explore the processes of pegmatite genesis. In this regard, the use of $\mathrm{Li}$ isotopic analysis provides powerful tools for unraveling the genesis of Li-bearing deposits such as granites and pegmatites, e.g., Barnes et al., 2012; Maloney et al., 2008; Teng et al., 2006a, since Teng et al. (2006a) and Tomascak et al. (1999) have demonstrated that $\mathrm{Li}$ isotope fractionation may occur at very low temperature (below $600^{\circ} \mathrm{C}$ ) during both the genesis and consolidation of rare-element rich pegmatite-forming melts.

However, according to Barnes et al. (2012), Li isotopic analysis of mineral separates should be favored over whole-rock analyses. Indeed, Li fractionation, i.e., the relative behaviour of ${ }^{6} \mathrm{Li}$ and ${ }^{7} \mathrm{Li}$ leading by a large mass difference, depends on the coordination states (in the case of silicates, the affinity of Li for octahedral or tetrahedral sites) of the coexisting Li-bearing phases, i.e., minerals, melts, and fluids. Micas are (i) markers of magmatic differentiation, e.g., Černý ,1991; Černý et al., 1995; Marchal et al., 2014; Roda et al., 1995; Roda-Robles et al., 2006; (ii) common constituents of most granitic pegmatites; and finally (iii) extensively studied regarding the behavior of $\mathrm{Li}$ in their crystal lattices (Brigatti et al., 2000, 2003). Moreover, crystallization of mica can occur 
during all stages of pegmatite consolidation, thereby allowing access to the entire history of consolidation through Li-isotope signatures (London, 2008).

Unfortunately, only a few analyses have been performed on mica separates (Barnes et al., 2012; Teng et al., 2006a; Tomascak et al., 1995; Wunder et al., 2007) and most of the published $\delta^{7} \mathrm{Li}$ data were obtained from mica sampled within a single mineralized pegmatite body, e.g. Tanco pegmatite, Manitoba, Canada; Tin Mountain pegmatite, Black Hills, South Dakota, USA, which makes it difficult to establish $\square$ at the scale of the pegmatite field $\square$ the relationships between the degree of magmatic evolution of each pegmatite and the evolution of its $\delta^{7} \mathrm{Li}$ signature.

In order to avoid problems related to scale and whole-rock analysis, we compiled $\delta^{7} \mathrm{Li}$ (\%o) mica analyses from each pegmatite type in the Monts d'Ambazac Pegmatite Field (MAPF, located in the northwest Massif Central, France). In this example, mica is a primary mineral and one of the main Li-bearing phases in the pegmatites. After a discussion of pegmatite classification, $\delta^{7} \mathrm{Li}(\%)$ mica analyses from pegmatites and their host granite will be compared. In light of these results we will then: i) evaluate the possible genetic relationships between the Mont d'Ambazac host granite and the pegmatites; ii) discuss both the pattern of Li-isotope fractionation; and iii) the possible utility of employing $\delta^{7} \mathrm{Li}$ analyses to delineate LCT-type mineral deposits. 


\section{Fractionation of $\mathrm{Li}$ isotopes in minerals and pegmatites}

\subsection{Li fractionation driven by bond-energy differences}

According to Wenger and Armbruster (1991), Li-isotopes are sensitive to the coordination states of $\mathrm{Li}$-bearing phases. The lightest isotope $\left({ }^{6} \mathrm{Li}\right)$ preferentially occupies octahedral sites (in mica for example) while ${ }^{7}$ Li favors tetrahedral sites (granitic melt). Thus the ${ }^{7} \mathrm{Li} /{ }^{6} \mathrm{Li}$ ratio may vary in agreement with the energy bonds in lattices, and is therefore likely to be affected by crystallization in which the influence of both tetrahedral and octahedral sites are active. Wunder et al. $(2007,2011)$ experimentally investigated Li-isotope fractionation between staurolite, lepidolite, spodumene and aqueous fluids (using a piston-cylinder press at $2 \mathrm{GPa}$ and temperatures ranging from 500 to $900^{\circ} \mathrm{C}$ ). Their results suggest that ${ }^{7} \mathrm{Li}$ is more concentrated in staurolite $\left(\Delta^{7} \mathrm{Li}_{\text {staurolite-fluid }}=+1.3 \%\right.$ at $\left.670^{\circ} \mathrm{C}\right)$ than in lepidolite $\left(\Delta^{7} \mathrm{Li}_{\text {mica-fluid }}=-2.55 \%\right.$ at $\left.350^{\circ} \mathrm{C}\right)$ or in spodumene $\left(\Delta^{7} \mathrm{Li}_{\text {spodumene-fluid }} \approx-4 \%\right.$ at $\left.500^{\circ} \mathrm{C}\right)$. Consequently, in the presence of an exsolved fluid phase or fluid-rich melt, ${ }^{7} \mathrm{Li}$ favours the fluid phase rather than the crystalline one (such as mica and spodumene). It therefore follows that $\delta^{7} \mathrm{Li}$ values (the deviation in parts per thousand relative to the L-SVEC (NIST 8545)) are expected to be affected by the crystallization of the various Li-bearing phases.

\section{2. diffusion-driven vs. mixing-driven Li fractionation}

In order to explain the systematic changes of $\mathrm{Li}$ concentrations and isotopic compositions in the country rocks with distance from the contact of the Tin Mountain pegmatite, Teng et al. (2006b) suggest that a solid-state diffusion of $\mathrm{Li}$ isotopes could induce Li fractionation. According to this study, Li-isotope fractionation is driven by 
thermal and Li-concentration gradients from the Li-rich pegmatite toward its country rocks. According to the same authors, this solid-state diffusion would be more efficient than the infiltration of Li-bearing fluid into the country rocks in explaining the systematic changes of Li-isotope ratios versus distance to the mineralized body. Li-isotope analyses performed on micas and whole rocks from the Tin Mountain pegmatite and host schist and amphibolite suggest that Li diffusion occurred over a distance of up to 10 $\mathrm{m}$ from the pegmatite into the country rock. Such diffusion occurred in an interconnected supercritical fluid phase exsolved during pegmatite crystallisation, which interacted with mineral crystals. Such Li diffusion is mainly controlled by the effective interconnected porosity (a property of the country rocks) and results in high $\delta^{7} \mathrm{Li}(\%)$ values and a strong [Li] increase within the country rock surrounding the Li-rich pegmatite.

This diffusive fractionation of lithium has been confirmed by Liu et al. (2010) by coupling lithium isotope analyses to 1-D and 2-D advection-diffusion numerical modeling for two country-rock profiles adjacent to Li-rich pegmatite dikes from the Florence County Pegmatite Field (Wisconsin, USA). Nevertheless, this diffusional fractionation continues to be debated, since Romer et al. (2014) have proposed a contrasting explanation to justify "exotic" Li-isotope compositions obtained on Thuringian granites. In contrast to the common view of Li transport being predominantly from the magma into the wallrocks, Romer et al. (2014) suggested that fluids $\square$ released from the wall rocks during contact metamorphism $\square$ flowed into the granites and/or the pegmatite systems. Under this hypothesis the mixing of magmatic fluids (characterised by low $\delta^{7} \mathrm{Li}$ values) and meteoric fluids (higher $\delta^{7} \mathrm{Li}$ values) is considered to be the main chemical process 
driving Li-isotope fractionation. In another geogical context, Krienitz et al. (2012) have rejected the diffusion-driven $\mathrm{Li}$ fractionation to explain the homogenization of $\mathrm{Li}$ isotopic composition of ocean island basalts $(2.4$ to $+4.8 \%$ ). In contrast to Teng et al. (2006b), Krienitz et al. (2012) suggested that Li diffusion is driven only at small scale, by the difference of chemical potential of the coexisting phases, e.g., crystal and melt/fluid. In addition to the Li-diffusion's definition, the same authors demonstrated that the weak variation of $\mathrm{Li}$ isotopic compositions of the basalts reflects the mantle source heterogeneity, e.g., the recycling of altered/ dehydrated oceanic crust, sediment and the reworking of mantle wedge material, rather than the diffusive reactions between basaltic melt and wall-rocks.

\section{3. $\delta^{7}$ Li values in LCT pegmatites}

In order to investigate lithium isotope fractionation during granite differentiation and its latest stage, pegmatite consolidation, numerous studies have been undertaken on both whole rocks and mineral separates (mainly spodumene and Li-rich mica): see Fig. 1.

Teng et al. (2006a, b) measured $\delta^{7} \mathrm{Li}$ in whole rocks and mineral separates from the Black Hills and the associated Tin Mountain pegmatite. These authors interpreted the low $\delta^{7} \mathrm{Li}(+1.4 \%$ ) values obtained on a simple pegmatitic vein (WC-9 in-situ pegmatite) as indicating the absence of Li-isotope fractionation during partial melting and fractional crystallization. This low $\delta^{7} \mathrm{Li}$ appears to reflect the source contribution. On the other hand, the heavier $\delta^{7} \mathrm{Li}(>+8 \%$ in average) found in Li-rich mica and spodumene are interpreted as the result of an extensive crystal fractionation (highly zoned pegmatite). The same interpretation has been proposed by Tomascak et al. (1995) for separated Li- 
muscovite. In addition to this magmatic fingerprint, mineral separates would have recorded any lithium isotope fractionation during fluid-crystal equilibrium. The increase of fluid content by fluid-phase separation or from an additional late fluid phase may have played a key role in producing heavier secondary isotopic compositions (Teng et al., 2006a).

Magna et al. (2010) made a similar interpretation on a single muscovite pegmatite, suggesting that crystal-melt isotope fractionation during the terminal stages of granite differentiation (marked by the increase in Rb-content) would be responsible for the high $\delta^{7} \mathrm{Li}(+8.9 \%$ ) , see Fig. 1. However, it becomes difficult to establish relationships between these results and the genesis of LCT-type pegmatite fields since all the values were obtained from single pegmatite.

Recently, Barnes et al. (2012) measured Li-isotope signatures from both wholepegmatites and mineral separates from the Little Nahanni Pegmatite Group (LCT pegmatites, NWT, Canada), Fig. 1. In this study, which focused on the consolidation process of the final $15 \%$ of pegmatite-forming melt, the highest $\delta^{7} \mathrm{Li}$ values $(+6 \%$ to + $12 \%$ ) obtained on whole-rocks are interpreted as the result of strong Li-isotope fractionation in an initially highly evolved peraluminous magma. The abundance of volatiles $\left(\mathrm{H}_{2} \mathrm{O}\right.$ and $\left.\mathrm{CO}_{2}\right)$, fluxes $(\mathrm{B}, \mathrm{F}, \mathrm{P})$ and rare-elements (including $\mathrm{Be}$ ) have a drastic effect on Li-isotope behavior, e.g., formation of strong Li-F bonds in the melt, favoring the partitioning of Li-isotopes (Barnes et al., 2012; Jahn and Wunder, 2009). Barnes et al. (2012) find that a low $\delta^{7} \mathrm{Li}$ is related to the less evolved pegmatite (characterized by high $\mathrm{K} / \mathrm{Rb}$ and $\mathrm{Li} / \mathrm{Cs}$ and low $\mathrm{Nb} / \mathrm{Ta}$ ratios) while, on the other hand, a high $\delta^{7} \mathrm{Li}$ value 
records an extreme Li-fractionation in a more evolved pegmatite (more advanced magmatic fractionation marked by low $\mathrm{K} / \mathrm{Rb}$ and $\mathrm{Li} / \mathrm{Cs}$ ratios). However, this study addressed only Li-rich pegmatites (spodumene subtype pegmatite, after Černý and Ercit, 2005) whereas simple Li-poor quartz-feldspar-muscovite pegmatites are more common at this scale, e.g., Linnen et al., 2012. It is therefore difficult to apply these interpretations to the genesis and evolution of an entire LCT-type pegmatite field.

\section{Geologic setting and sample descriptions}

\subsection{Monts d'Ambazac Pegmatite Field}

The Monts d'Ambazac rare-element pegmatite field (Limousin, France) is mainly emplaced within the Saint Sylvestre Granitic Complex (SSGC, Fig. 2). These rareelement pegmatites belong to an extended rare-element magmatic belt running through the northern edge of the French Massif Central (FMC; see Marignac and Cuney, 1999), dated at approximately 309 Ma, e.g., Cuney et al., 1992, 2002; Raimbault and Burnol, 1998. More than 100 pegmatitic bodies have been identified in the MAPF (Burnol, 1974; Patureau, 1987; Raimbault, 1998). Most of them are beryl-rich and match the beryl type of the LCT group defined by Černý and Ercit (2005). Few of these pegmatite dikes match the intermediate lepidolite-petalite subtype of the LCT group (Černý and Ercit, 2005). These Li-rich bodies are found in the southern part of the SSGC, most of them intrusive into the coarse-grained $\gamma_{1}$ type St Sylvestre granite (Fig. 2) with a few exceptions intruding the para-autochtonous metamorphic unit that hosts the granite. The Chédeville dike is the largest of the most differentiated bodies within the area. This LiBe-Nb-Ta-Sn-rich pegmatite, which intrudes the granite, has been dated at $309 \pm 0.9 \mathrm{Ma}$ 
$\left({ }^{40} \mathrm{Ar} /{ }^{39} \mathrm{Ar}\right.$ method on lepidolite, Cheilletz et al., 1992) and $309 \pm 5 \mathrm{Ma}$ (LA-SF-ICP-MS U$\mathrm{Pb}$ on columbite-tantalite group minerals, Melleton et al., 2011), whereas the granite of the SSGC has been dated at $324 \pm 4 \mathrm{Ma}$ (TIMS U-Pb on zircon and monazite, Hollinger et al., 1986).

A recent study by Deveaud et al. (2013) shows that the emplacement of the MAPF is associated with a $\mathrm{N} 015^{\circ}$ fault system but does not seem to be related to the surrounding granites. However, the parental source of these rare-element pegmatites remains unknown.

\subsection{MAPF pegmatite classification}

The pegmatite bodies of the MAPF can be classified using multiple parameters: the pegmatite/aplite volume ratio; textural and mineralogical observations; width and extension of dike. Following this approach, six pegmatite types have been identified:

Type I pegmatite is barren, characterized by a narrow width $(0.5 \mathrm{~m})$ and small extension $(<1 \mathrm{~m})$. It is exclusively granitic in composition and limited to quartz, kfeldspars, biotite and muscovite. The graphic texture within k-feldspars is its only distinguishing criterion from the coarse-grained $\gamma_{1}$ host granite. This type will not be discussed further in this work.

Type II pegmatite is slightly larger than Type I ( 1 m) and exhibits a small extension ( $1.5 \mathrm{~m})$. Contacts with host-rocks are very progressive. The mineralogy of Type II is similar to Type I with the addition of rare beryl and columbite-tantalite in limited amount. Its structure is very simple with two main units: graphic unit and intermediate unit but it 
lacks a quartz core (Fig. 3A). Type II pegmatite may potentially contain a fine-grained leucocratic unit with cavities mainly filled by quartz and muscovite.

Type III pegmatite is about $5 \mathrm{~m}$ width on average. Type III mineralogy is identical to Type II with the addition of albite. Its structure is more complex since Type III is zoned from rim to core by five units: an external graphic unit; an intermediate unit; a second pegmatitic unit recognizable by the presence of skeletal quartz and biotite crystals; a blocky zone and, finally a quartz core. This type is characterized by the occurrence of an additional albitic unit with disseminated quartz and muscovite, which overlaps the sequence described above. Type III may also develop more or less continuous layered aplitic units, on the external parts of the pegmatite (Fig. 3B).

Type IV pegmatite is 5 to $10 \mathrm{~m}$ in width on average. Its mineralogy and internal zonation are quite similar to Types II and III but marked by the appearance of zinnwaldite and the development of phosphatic phases, e.g., apatite, in the inner portion of the pegmatite (Patureau, 1987). The layered aplitic unit is common in Type IV and larger than in Type III. In some cases, Type IV may be bounded by an extensive biotite layer at its contact with the host granite (Fig. 3C). The quartz core is also considerably larger (meter scale) in this type of pegmatite than in Types II and III (Fig. 3D).

Type $\mathbf{V}$ pegmatite is $15 \mathrm{~m}$ in width on average. It is characterized by the near absence of dark mica. Pegmatite zonation is similar to Type IV with an elongated quartz core and an extended aplitic unit developed in the external portion of the pegmatite, which significantly reduces the pegmatite/aplite volume ratio. The aplitic unit of Type $V$ is mainly composed of quartz, albite and garnet (Fig. 3E). 
Type VI pegmatite is exposed only on the southern edge of the SSGC. The width of these pegmatitic dikes varies, depending on their host, from a few centimeters in the gneisses of the para-autochtonous unit up to some $3 \mathrm{~m}$ on average in granite (Raimbault, 1998). In either case, the contact with the host rock is sharp. The mineralogy of Type $\mathrm{VI}$ is quite complex with quartz, k-feldspars, albite, muscovite, zircon, lepidolite, petalite and phosphates, e.g., amblygonite, montebrasite, apatite, and bertrandite. Sn, $\mathrm{Nb}$ and Ta oxides are also present (Raimbault, 1998). The internal structure of Type VI pegmatites is composed of four units which are repeated throughout the dike: 1) blocky zone containing petalite $(\mathrm{cm})$ and a fine-grained quartz-lepidolite association; 2) a layered blocky zone; 3) a massive aplitic unit with mainly quartz, albite, muscovite and lepidolite occurrences; and 4) a complex unit with mainly petalite, quartz and lepidolite blocks in a layered and disrupted matrix by triangular k-feldspars (Fig. F).

\subsection{Sampling and micas}

\subsubsection{Sampling}

Pegmatite name refers to locality, \# year of sampling and pegmatitic unit; 01 for intermediate unit, 02 for internal and 03 for undetermined.

All beryl-subtype pegmatites exhibit a common intermediate unit mainly composed of quartz, k-feldspars, muscovite and biotite crystals averaging $1.5 \mathrm{~cm}$ in size. Taking into account the diversity of pegmatite types, textures and accessibility, dark and white micas from eight pegmatites were sampled in each intermediate unit (Sample locations shown in Fig. 2). The amount of biotite significantly decreases with pegmatitic differentiation from Type II to Type VI. More evolved pegmatites of Type 
IV and V - (Samples VH, CB and CHED) are devoid of biotite or contain biotite in limited amounts in the external intermediate unit. Given this observation, the comparison of chemical and Li-isotopic compositions of biotite and muscovite is not possible for Type II (biotite only, PB), Type V (white mica only, CB, VH), or Type VI (lepidolite only, CHED). Both external and core units from two pegmatite bodies of Type IV (Sample MB) and Type V (Sample CB) were sampled, to study Lifractionation within a single mineralized body. Finally, $\delta^{7} \mathrm{Li}(\%)$ in biotite from the $\gamma_{1}$ Saint Sylvestre granite (SSGC\#13) was analyzed to compare with that from micas in pegmatite.

\subsubsection{Microscopic description}

In most cases, biotite is about $1 \mathrm{~cm}$ in size. It contains apatite and/or quartz inclusions. Some of these biotite crystals are fractured and the fractures are filled with quartz and k-feldspars (Fig. 4A, B). Only one generation of biotite has been recognized in each type.

In contrast, muscovite is present in all pegmatite types and provides a possible overview of the entire pegmatite suite. Two main generations of muscovite are recognized under the optical microscope. The first generation is characterized by large, more or less altered crystals (Fig. 4C) and a second generation composed of fine-grained muscovite occurs as a pseudomorphic replacement, mainly of feldspars (Fig. 4D). No optical distinction could be made between muscovites from distinct pegmatite types. However, in the less evolved pegmatites we observe "books" of muscovite sheets, which unlike primary muscovite from the highly evolved 
pegmatites is disseminated in the matrix. Primary intergrowths of biotite and muscovite have been observed from Type II to Type IV pegmatites.

Lepidolite has been described only in Type VI pegmatites. Lepidolite is firstly recognizable as having a lower birefringence color than muscovite and secondly because it rarely occurs in single crystals but more typically in fine-grained masses (quartz and lepidolite crystals $<1 \mathrm{~mm}$ in size, Fig. 4E). No particular alteration is observed in this sample.

\section{Analytical procedures}

\subsection{In situ analysis}

In order to assess the variability of mineral compositions, the major elements and $\mathrm{Li}$ contents of micas were measured, respectively using an SX-5 CAMECA electron microprobe at the Institut des Sciences de la Terre d'Orléans (ISTO), and Laser ablation ICP-MS (Laboratoire Magma et Volcan, Clermont Ferrand, France). The measurements were performed only on separated fresh mica crystals mounted in epoxy (Fig. 4F) and are presented in Table 1. Microprobe analyses were made at $15 \mathrm{kV}$, with a mean beam current of $10 \mathrm{nA}$, an average diameter of between 3 and $5 \mu \mathrm{m}$, and a counting time of 20 sec for analytical peaks and $10 \mathrm{sec}$ for lower and upper backgrounds. The standards used for calibration were as follows: albite ( $\mathrm{Si}, \mathrm{Na}, \mathrm{K}), \mathrm{MgO}(\mathrm{Mg}), \mathrm{Al}_{2} \mathrm{O}(\mathrm{Al})$, topaz $(\mathrm{F})$, apatite $(\mathrm{P})$, andradite $(\mathrm{Ca})$, orthoclase $(\mathrm{K}), \mathrm{Fe} \mathrm{e}_{2} \mathrm{O}(\mathrm{Fe})$, vanadinite $(\mathrm{Cl})$ and $\mathrm{MnTi}$ standard (Mn, Ti). The lithium contents of micas were obtained using an Agilent 7500 series inductively coupled plasma mass spectrometer coupled to a Resonetics $193 \mathrm{~nm} \mathrm{ArF}$ Excimer Laser with a standard $~ 30 \mathrm{~cm}^{2}$ cell and $100 \%$ flushing with $\mathrm{He}$ (mixed with $\mathrm{Ar}+$ $\mathrm{N}_{2}$ after the cell). The laser beam was focused to a $25-\mu \mathrm{m}$ spot, with energy of $5 \mathrm{~J} / \mathrm{cm}^{2}$ 
and a $4 \mathrm{~Hz}$ repetition rate; the beam was rastered along a 100-200 $\mu \mathrm{m}$ line at $10 \mu \mathrm{m} . \mathrm{s}^{-1}$. Data calibration was achieved using the bracketing technique over an NIST 612-glass (Pearce et al., 1997) analyzed every 20 spots. A BCR-glass was used as control standard (Jochum et al., 2005).

\subsection{Composition and Li-isotopic signatures of mica solutions}

Measurements of Li-isotopic signatures of mica solutions were performed in the Laboratory Division of the BRGM (Orléans, France) and are presented in Table 2 and Table 3 respectively. After having been handpicked, fresh micas were dissolved following the procedure of Millot et al. (2010). Aliquots of the solution were analyzed beforehand for trace elements, i.e., Be, $\mathrm{Ba}, \mathrm{Cs}, \mathrm{Li}, \mathrm{Nb}, \mathrm{PO}$, Rb, $\mathrm{Sn}, \mathrm{Sr}, \mathrm{Ta}, \mathrm{Ti}$ and $\mathrm{Zn}$, using ICP-AES. The chemical separation/purifications were performed by ion chromatography in a clean laboratory, as required to obtain a pure mono-elemental solution (technical procedure modified from James and Palmer, 2000). Lithium isotopic compositions were measured on a double focusing Neptune MC-ICP-MS (ThermoFinnigan). ${ }^{7} \mathrm{Li} /{ }^{6} \mathrm{Li}$ were normalized to an L-SVEC standard solution (NIST SRM 8545, Flesch et al., 1973) following the standard-sample bracketing method (see Millot et al., 2004 for more details). The external reproducibility of repeatedly analyzed standard solutions (seawater IRMM BCR-403 and basalt JB-2) is given as $2 \sigma( \pm 0.5 \%$ ). A $2 \sigma_{\mathrm{m}}$ internal error ranging from 0.1 to $0.2 \%$ was obtained for each measurement. For each sample, the number of replicates is taken into account in the internal error $\left(2 \sigma_{\mathrm{m}}\right)$. Instrument operating conditions and the chemical procedures employed are described in Millot et al. $(2004,2010)$. 


\section{$\underline{\text { 5. Results }}$}

\subsection{Mica composition as a marker of magmatic differentiation}

Major-element compositions of white and dark micas are plotted according to Tischendorf et al. (1997), Fig. 5. In situ measurements of Li (LA-ICPMS) are preferred to more precisely determine white and dark mica compositions and to investigate the $\mathrm{Li}$ distribution at crystal scale. Whereas the white mica compositions are fairly homogeneous and correspond to Li-phengite and lepidolite $([\mathrm{Mg}-\mathrm{Li}]<-3)$, biotite composition exhibits a much larger variability, trending from Fe-biotite to the protolithionite group, corresponding to enrichment in Al and Li from Type II to Type V pegmatites. The $\mathrm{Fe} /(\mathrm{Fe}+\mathrm{Mg})$ ratio increases with decreasing $\mathrm{Al}_{\mathrm{IV}}$ and $\mathrm{Ti}$ from Type II to Type $\mathrm{V}$ pegmatites, whereas the same $\mathrm{Fe} /(\mathrm{Fe}+\mathrm{Mg})$ ratio is proportional to the $\mathrm{Al} \mathrm{VI}^{-}$and Mn- contents of biotites from the less differentiated Type II pegmatite to the more differentiated Type V pegmatite (Fig. 6). Muscovite samples are characterized only by the variation of their $\mathrm{Fe} /(\mathrm{Fe}+\mathrm{Mg})$ ratios, the lowest value being obtained for Type III muscovite whereas the highest value is obtained on Type $V$ muscovite (Fig. 6). However, in both cases, white and dark mica compositions are distinguished by their pegmatite type.

The $\mathrm{K} / \mathrm{Rb}$ ratio in mica decreases with the degree of pegmatite-forming melt evolution, e.g., Černý et al., 1981; Foord et al., 1995; Li et al., 2015; Marchal et al., 2014. The Li vs. K/Rb ratio (Fig. 7) shows a good agreement between the micas' compositions and the classification previously described. Type II pegmatite has the highest $\mathrm{K} / \mathrm{Rb}$ and the lowest [Li] and is therefore likely to be the less fractionated magma. Biotite aliquots are 
richer in $\mathrm{Li}$ (from $\sim 2100 \mathrm{ppm}$ to $\sim 5500 \mathrm{ppm}$ ) and characterized by lower $\mathrm{K} / \mathrm{Rb}$ ratios (between 15 and 34) than muscovite aliquots, with ranges of from 627 to $2807 \mathrm{ppm}$ and 18 to 68 ppm respectively (Fig. 7). One sample (VH\#1302) of Type V muscovite is distinguished from the other by having the highest [Cs] and [Sn] and the lowest $\mathrm{K} / \mathrm{Rb}$ ratio ( 18). Trace element contents in white and dark mica (Li, Cs Be and Sn, Fig. 8) also reveal compositional changes that are in agreement with the pegmatite classification. However, trace element contents in white mica are systematically lower than in dark mica, except for $[\mathrm{Be}]$ and $[\mathrm{Sn}]$.

\section{2. $\delta^{7} L i(\%)$ of mica}

The $24 \mathrm{Li}$ isotope analyses from MAPF micas performed in this study exhibit a range of $\delta^{7} \mathrm{Li}$ values of from -3.6 to $+3.4 \%$ (Table 3 and Fig. 9). These results are consistent with those obtained by Teng et al. (2004) on the average upper continental crust of $0 \pm 2 \%$ (at $1 \sigma)$ and on I- and S-type granite matrices $(-2.5$ to $+2.7 \%$ ). However, most of the values fall within a narrow range: between -2 and $+2 \%$. The two outliers have lower ($3.6 \%$ ) and higher $\left(+3.4 \%\right.$ ) $\delta^{7} \mathrm{Li}$ values. The white mica providing the highest value corresponds to an internal part of a Type $\mathrm{V}$ pegmatite. Interestingly, white mica from the intermediate part (CB\#1301) of the same pegmatite gives a $\delta^{7} \mathrm{Li}$ value of $-1.7 \%$. Similarly, three distinctive biotite $\delta^{7} \mathrm{Li}$ values were also obtained from different parts of a single pegmatite body, ranging from -1.3 to $+0.8 \%$ (MB pegmatite, Fig. 9 ). This narrow $\delta^{7} \mathrm{Li}$ range does not show any clear relationship to pegmatite type or even Li content in mica. The $\delta^{7} \mathrm{Li}$ value obtained from biotite of the Saint Sylvestre Granite $(-1.5 \%$; SSGC\#13; Fig. 9) is similar to $\delta^{7} \mathrm{Li}$ analyses of biotite from Type IV pegmatite (Sample 
$\mathrm{MB} \# 1303)$ and is no different from the main range of $\delta^{7}$ Li defined by most of the micas extracted from pegmatites of the MAPF.

Fig. 10 shows $\delta^{7} \mathrm{Li}(\%)$ analyses of mica aliquots versus trace element contents $(\mathrm{Be}, \mathrm{Cs}$ and $\mathrm{Rb}$ ) and $\mathrm{Nb} / \mathrm{Ta}$ ratio. According to London (2008), these particular elements can provide some insights regarding fractionation behavior. [Cs] increases in differentiated pegmatitic magma while $[\mathrm{Be}]$ decreases. $\mathrm{Rb}$ is commonly strongly compatible with potassium-bearing minerals such as micas during pegmatite consolidation (Černý et al., 1995). Finally, the $\mathrm{Nb} / \mathrm{Ta}$ ratio is supposed to decrease with magmatic differentiation since high [Li] is required to precipitate Ta-oxides from a granitic melt, e.g., Linnen, 1998.

Fig. 10 does not show any clear relationship between $\delta^{7} \mathrm{Li}$ and $[\mathrm{Rb}]$, [Be] or [Cs]. Muscovite shows a very limited variation of $[\mathrm{Cs}]$, $[\mathrm{Be}]$ but $\delta^{7} \mathrm{Li}(\%)$ show a wide variability. On the other hand, [Cs] and [Be] contents in biotite are much less variable with a narrower $\delta^{7} \mathrm{Li}$ range. Although [Rb] displays considerable variability in both muscovite and biotite, no correlation can be clearly established. Similarly, the $\mathrm{Nb} / \mathrm{Ta}$ ratio variation cannot be related to $\delta^{7} \mathrm{Li}$ behavior. Interestingly, lepidolite from Type $\mathrm{VI}$ has the highest $[\mathrm{Be}]$ and lowest $\mathrm{Nb} / \mathrm{Ta}$ ratio, but its $\delta^{7} \mathrm{Li}$ is very similar to any other mica.

\section{Discussion}

\subsection{White and dark mica composition as reflective of pegmatite differentiation}

In this study, in situ Li content is used instead of estimating Li by electron microprobe which drastically minimizes [Li] (Tischendorf et al., 1997; Fig. 5). Taking account these 
higher [Li] values, we can justify the outliers (Type V dark mica, Type VI white mica) in the Tischendorf et al. (1997) classification as belonging to the zinnwaldite and lepidolite groups respectively. The dark micas sampled in Type II pegmatites are more ferromagnesian than those sampled in Type $\mathrm{V}$ pegmatites, which are characterized by an increase of $[\mathrm{Li}]$ and a decrease in the $\mathrm{Fe} /(\mathrm{Fe}+\mathrm{Mg})$ ratio. White mica compositions are more homogenous with only slight variation of [Mg-Li] which decreases for Types IV and V. This result is also consistent with the pegmatites field classification. Lepidolite is the richest in $\mathrm{Li}$, defined by [Mg-Li] lower than -5 . In addition, white and dark micas' major compositions vary according to the pegmatite type. Therefore, mica composition reflects the degree of magmatic evolution at the MAPF scale. This result is confirmed by the decrease of $\mathrm{K} / \mathrm{Rb}$ ratio with the increase of [ $\mathrm{Li}$ ] in each aliquot (Fig. 7). Indeed, the $\mathrm{K} / \mathrm{Rb}$ ratio in muscovite decreases with [Li] from Type II to Type $V$ pegmatite, ranging from 68 to 18 with 500 and $2000 \mathrm{ppm}$ Li respectively. In the same way as muscovite, the K/Rb ratio in biotite decreases with [Li] from Type II to Type IV. However, dark micas exhibit lower $\mathrm{K} / \mathrm{Rb}$ ratio values, ranging from $\sim 33$ to $\sim 15$, and the highest [Li] (2000 to 5500 ppm). This result is consistent with the experimental works of Icenhower and London, (1995) which demonstrate that at a similar temperature, $\mathrm{Li}$ is more compatible with biotite (partition coefficient of $\mathrm{Li} \mathrm{D}_{\mathrm{Li}}^{\mathrm{Bt}}{ }^{\mathrm{B} \text { elt }}$ ranges from 1.0 to 1.7$)$ than with muscovite $\left(\mathrm{D}_{\mathrm{Li}}\right.$ Ms/melt $\sim 0.8$ ). The partition coefficient of $\mathrm{Rb}$ between residual melt and tri- and dioctahedral mica is unknown. However, the positive correlation between $\mathrm{Li}$ and $\mathrm{Rb}$ during the evolution of magmatic differentiation is well constrained and can explain the lower $\mathrm{K} / \mathrm{Rb}$ ratios observed in white mica. Considering that dark mica crystallizes before muscovite at the onset of pegmatite consolidation, the residual pegmatite-forming melt from which muscovite crystallizes should be depleted in Li. 
In addition to major and $\mathrm{Li}$ elements, we demonstrate that the magmatic fractionation trend observed in white and dark mica aliquots is also recorded by trace elements such as [Cs], [Be] and [Sn]. These trace-element concentrations increase with pegmatite type, i.e., with decreasing $\mathrm{K} / \mathrm{Rb}$ ratio. In contrast to [Li] and [Cs], muscovite shows the highest $\mathrm{Be}$ and $\mathrm{Sn}$ contents. Just as with the $\mathrm{K} / \mathrm{Rb}$ ratio in muscovite, we suggest that Sn and Be become more concentrated in white mica because at the beginning of pegmatite consolidation the melt becomes saturated in biotite before muscovite. The muscovite outlier (VH\#1302) is characterized by the highest $\mathrm{K} / \mathrm{Rb}$ ratio $(\sim 18)$, $\mathrm{Cs}(\sim 300$ ppm) and Sn contents ( $550 \mathrm{ppm})$. In order to explain this outlier composition, we suggest that this white mica sample crystallized within an interior portion of a Type $\mathrm{V}$ pegmatite body. Additionally, we believe that this "exotic" rare element composition reflects a distinct magma source/ or a different contribution of crustal source than that from of the Type V CB pegmatite.

\subsection{Insignificant Li-isotope fractionation throughout the MAPF}

The mica $\delta^{7} \mathrm{Li}$ values from the MAPF range from -3.6 to $+3.4 \%$. However, these analyses geographically cover the entire MAPF and a small part of the surrounding Saint-Sylvestre two-mica granite. No dispersion is observed within the data, as was pointed out by Barnes et al. (2012) and Teng et al. (2006a) for certain evolved granitepegmatite systems (Fig. 1). However, this $\delta^{7} \mathrm{Li}$ range is similar to the range of $\delta^{7} \mathrm{Li}$ values (-4 to $+2 \%$ ) obtained on Erzgebirge granites by Romer et al. (2014), Fig. 11 .

Most pegmatite and granite $\delta^{7} \mathrm{Li}$ signatures range from -2 to $+2 \%$ (dotted line, Fig. 9). These $\delta^{7} \mathrm{Li}(\%)$ values are independent of [Li], ranging from 800 to $\sim 12,000 \mathrm{ppm}$. We 
distinguish two outliers that match the lowest (PB\#1301) and highest (CB\#1302) $\delta^{7} \mathrm{Li}$ (\%). One of these outliers corresponds to muscovite collected from an inner portion of the CB pegmatite body (CB\#1302). Indeed, this Li-isotope fractionation is believed to be internal to the CB pegmatite body, with the increase of $\delta^{7} \mathrm{Li}(\%)$ from the intermediate "less differentiated" magma (CB\#1301; $-1.7 \%$ ) up to the internal "more differentiated" residual pegmatite-forming melt (CB\#1302; $+3.4 \%$ ) of Type $V$ pegmatite. Such a result is consistent with previous work on Li-isotope fractionation behavior inside pegmatite dikes (Tin Mountain pegmatite, Teng et al., 2006a; San Diego County pegmatite, Maloney et al., 2008). However, such internal fractionation is not observed in other pegmatites in which intermediate and internal units have been sampled (AN, MA2 and MB pegmatite bodies; Table 3). We suggest that fractional crystallisation-driven Li-isotope fractionation is recorded only in Type $\mathrm{V}$ pegmatite. The large volume of this pegmatite (15 m width on average) could be responsible of the development of different pegmatite units with distinct $\delta^{7} \mathrm{Li}$ signatures increasing towards a quartz core. According to these results, the $\delta^{7} \mathrm{Li}(\%)$ contents of white and dark micas from pegmatites and from the SSGC are independent of fractional crystallization, and thus from their degree of magmatic evolution.

\subsection{Li-isotope variation across the MAPF}

In order to investigate $\mathrm{Li}$ isotope behavior, we plotted $\delta^{7} \mathrm{Li}(\%)$ against the elements $\mathrm{Be}$, Cs and $\mathrm{Rb}$ and the $\mathrm{Nb} / \mathrm{Ta}$ element ratio. As with [Li], [Be], [Cs] and [Rb] do not impact $\delta^{7}$ Li variation. In fact, dark mica presents more variable $[\mathrm{Be}]$ and $[\mathrm{Cs}]$ for a narrow range 
of $\delta^{7} \mathrm{Li}(-1.5$ to $+1.8 \%$ ), whereas muscovite shows a more variable $[\mathrm{Rb}]$ and $\mathrm{Nb} / \mathrm{Ta}$ ratio for a wider range of $\delta^{7} \mathrm{Li}(-3.6$ to $+3.4 \%)$.

Although lepidolite has one of the lowest $\delta^{7} \mathrm{Li}(-2 \%)$, it matches the highest $[\mathrm{Be}]$ and the lowest $\mathrm{Nb} / \mathrm{Ta}$ ratio. This trace element concentration is consistent with the high degree of magmatic fractionation of Type VI pegmatite bodies, especially as high [Li] is required for the saturation of Ta in granitic melts, e.g., Linnen, 1998. However, as with biotite and muscovite, the degree of magmatic evolution of Type $\mathrm{VI}$ pegmatites does not control the Li-isotope composition of lepidolite. In order to explain this low lepidolite $\delta^{7} \mathrm{Li}$ $(-2 \%)$, it is important to take into account $\mathrm{Li}$ fractionation behavior in the trioctahedral lepidolite structure. Wunder et al. (2007) experimentally demonstrated that the heavy ${ }^{7} \mathrm{Li}$ isotope prefers to remain in the fluid phase than in the lepidolite group's crystal lattice $\left(\Delta^{7} \mathrm{Li}_{\text {mica-fluid }}=-2.55 \%\right.$, at $\left.350^{\circ} \mathrm{C}\right)$ at temperatures around that observed during the latest stage of pegmatite consolidation, e.g., Sirbescu and Nabelek, 2003. The lepidolite $\delta^{7} \mathrm{Li}$ ($2 \%$ ) being similar, it could have recorded the fractionation of $\mathrm{Li}$ isotopes between the crystallizing lepidolite and a late interacting fluid phase. This physico-chemical process could be responsible for ${ }^{6} \mathrm{Li}$ enrichment in lepidolite crystallizing from the residual pegmatite-forming melt. This fluid-melt separation is consistent with major rare element bearing phases (e.g., Jahns and Burnham, 1969; London and Morgan, 2012 and reference therein) such as massive lepidolite, and petalite that are the most abundant of the entire MAPF. Nevertheless, the internal zonation of the CHED pegmatite dike (described in Section 3.2 above) shows no evidence of the consolidation of a late fluidrich melt, which are commonly characterized by rare element-rich extensive recovering albitic units. Consequently, the overprinting of this primary Li isotope composition by the 
release of a fluid-rich melt seems unlikely. Nevertheless, additional measurements in other pegmatitic units of this dike (i.e., in crystals which could nucleate from the buoyant aqueous rare element-bearing fluid) should be obtained to clarify this point.

\subsubsection{Li-diffusional fractionation?}

As suggested by Teng et al. (2006b), the low isotopic compositions obtained on muscovite and biotite micas could be the consequence of $\mathrm{Li}$ isotope diffusion induced by fluid-rock interaction during the emplacement of pegmatitic dikes. Parkinson et al. (2007) demonstrate that this fluid-assisted $\mathrm{Li}$ isotopes diffusion is able to overprint primary mineral compositions over very short periods. However, there is no evidence of metasomatic alteration in the vicinity of the pegmatite-granite contact, and the granite's $\delta^{7} \mathrm{Li}(\%)$ and $[\mathrm{Li}]$ are no higher than the pegmatites'. In addition to the lack of evidence of alteration, the chemical composition trends of mica do not reflect a possible overprinting by a secondary fluid phase. Knowing that Teng et al. (2006b) demonstrated that the Li diffusion can occur over a distance of up to $10 \mathrm{~m}$ from the Li-rich pegmatite into the country rock, additional measurements in the vicinity of the CHED dike (see map for the location) would be required to clarify this point.

\subsubsection{Mixing-driven Li isotope fractionation?}

As suggested by Romer et al. (2014), fluid-triggered wall-rock interactions may involve a shift in the primary Li isotope compositions of granites. In this case, meteoric fluids released during the intrusion of granites (i.e., development of a metamorphic contact aureole) influx into granitic magma leading the overprint of $\mathrm{Li}$ isotope compositions of magmatic fluids $\square$ from which Li-bearing phases crystallize $\square$ by meteoric fluids. 
However, as previously mentioned, there is no evidence of alteration to support mixingdriven Li-isotope fractionation during the emplacement of these pegmatite dikes. Additionally, the Li isotope composition of the wall rocks, in our case the SSGC, is little different from that of the pegmatites. These results confirm that the $\delta^{7} \mathrm{Li}(\%)$ values of the micas are primary and are not controlled by mixing-driven Li isotope fractionation.

\subsection{3. $\delta^{7} \mathrm{Li}$ as reflecting inherited signatures of crustal protoliths}

As shown in Fig. 11, the highest primary mica $\delta^{7} \mathrm{Li}(\%)$ values are interpreted as the result of an extreme granitic fractionation and related to the highly evolved pegmatiteforming melt, e.g., Magna et al., 2010; Teng et al., 2006a; Tomascak et al., 1995. However, in this study, we obtain similar $\delta^{7} \mathrm{Li}$ values (\%) for micas from distinct pegmatite types and from granite, which clearly indicate that these primary signatures are mainly controlled by the chemical composition of crustal source rocks and that they are not significantly affected by crustal anatexis or fractional crystallization mechanisms. Similar observations are made by Romer et al. (2014) who report a similarly narrow range of granite $\delta^{7} \mathrm{Li}(\%)$ values, Fig. 11 . These $\delta^{7} \mathrm{Li}$ signatures are interpreted as "isotopic fingerprints for the source of crustal melts" (Romer et al. 2014). As has been proposed for the Erzgebirge granites, we suggest that the MAPF micas' $\delta^{7} \mathrm{Li}$ values $(\%)$ correspond to inherited isotopic signatures from a common type of crustal source for both SSGC and the MAPF. Furthermore, the geochemically different pegmatite types characterized by distinct major rare element-bearing phases- may reflect the contrasting contributions of crustal protoliths. We therefore suggest that the more-evolved pegmatite type has not issued from an extreme magmatic fractionation of the less-evolved 
pegmatite type. These observations are consistent with the spatial statistical analysis applied to the MAPF by Deveaud et al. (2013), to describe the 2-D spatial distribution of the various pegmatite types. According to this study, the emplacement models for berylsubtype and lepidolite-petalite subtype pegmatites are different and controlled by different structural settings. The sequential nature of the contributions of crustal protoliths could also be responsible for the different major rare element-bearing phases throughout the MAPF. Accordingly to these results, the $\delta^{7} \mathrm{Li}(\%)$ values of primary micas cannot constitute an isotopic tracer for LCT-type granitic pegmatites and thus cannot be used to track the most economically-interesting pegmatite bodies. These results are not in agreement with previous studies performed on single mineralized pegmatite bodies and/or similar pegmatite subtypes (Barnes et al., 2012; Magna et al., 2010; Teng et al., 2006a; Tomascak et al., 1995). However, they should play a very useful role in understanding the nature and the differentiation processes of various crustal contributions for the genesis of LCT-type pegmatite-forming melts.

\section{Conclusions}

Although the chemical compositions of some micas show a magmatic differentiation trend from the less to the more evolved pegmatite (increase of [Li] and decrease of element ratios such as $\mathrm{K} / \mathrm{Rb}$ and $\mathrm{Nb} / \mathrm{Ta}$ ), this magmatic fractionation trend is not seen in the $\delta^{7} \mathrm{Li}$ values $(\%)$ of the micas. All the mica samples fall within a range of from -3.6 to $+3.4 \%\left( \pm 0.2 \sigma_{\mathrm{m}}\right)$.

We show that Li-isotope fractionation in mica species such as biotite, muscovite and lepidolite from the MAPF has not been affected by the fractional crystallisation and 
crustal anatexis processes in a significant manner. In contrast with published data, we do not observe an increase of $\delta^{7} \mathrm{Li}(\%)$ with degree of pegmatite differentiation.

Moreover, biotites from the surrounding SSGC exhibit similar compositions to biotite sampled in the highly evolved pegmatite dikes.

Firstly, these results demonstrate that the extreme magmatic fractionation of the peraluminous Saint-Sylvestre granite is not the initiating mechanism at the origin of the MAPF's genesis. Secondly, the evolutions of the magmatic and isotopic compositions of the pegmatite-forming melts are unrelated to each other.

Finally, we suggest that the light isotopic values found in micas are inherited from a common metasedimentary crustal source for both the SSGC and the pegmatites. The magmatic fractionation trend observed in micas and the various rare element-bearing major phases in pegmatites constitute clear evidence of the contrasting contributions of crustal protoliths.

\section{Acknowledgments}

We especially thank Anne-Marie Gallas and Catherine Guerrot for their involvement during sample preparation. We are grateful to Jean-Luc Devidal for the use of LA-ICPMS (LMV, Clermont-Ferrand, France) and to Guillaume Wille for the use of the electron microprobe (BRGM, France). We also thank Laurent Guillou-Frottier for his comments and review of the manuscript, Pr. P.Tomascak and an anonymous reviewer for their cogent comments, which contributed to improving this paper. This research was funded by the French Geological Survey (BRGM), Région Centre, and Labex VOLTAIRE (ANR10-LABX-100-01). 


\section{References}

Barnes, E.M., Weis, D., Groat, L.A., 2012. Significant Li isotope fractionation in geochemically evolved rare element-bearing pegmatites from the Little Nahanni Pegmatite Group, NWT, Canada. Lithos 132-133, 21-36. doi: 10.1016/j.lithos.2011.11.014

Brigatti, M.F., Lugli, C., Poppi, L., Foord, E.E., Kile, D.E., 2000. Crystal chemical variations in $\mathrm{Li}-$ and Fe-rich micas from Pikes Peak batholith (central Colorado). Am. Mineral. 85, 1275- 1286.

Brigatti, M.F., Kile, D.E., Poppi, L., 2003. Crystal structure and chemistry of lithiumbearing trioctahedral micas- 3T. Eur. J. Min. 15 (2), 349-355.

Burnol, L., 1974. Beryllium geochemistry and concentrations in leucogranites of French Massif Central. Relationships between geochemical granitic characteristics and endogenous deposits of acide type (Be, Sn, Li) or of late reshuffle. (U, F, Pb, Zn). Mém. Bur. Rech. Géol. Min. 85, p. 168 (in French).

Cameron, E.N., Jahns, R.H., McNair, A.H., Page, L.R., 1949. Internal structure of granitic pegmatites. Econ. Geol. Monograph 2.

Černý, P., 1991. Rare-element granitic pegmatites, part I. Anatomy and internal evolution of pegmatites deposits. Geosc. Can 18, 49-67. 
Černý, P., Ercit, T.S., 2005. The classification of granitic pegmatites revisited. Can. Mineral. 43, 2005-2026.

Černý, P., Trueman, D.L., Ziehlke, D.V., Goad, B.E., Paul, B.J., 1981. The Cat LakeWinnipeg River and Wekusko Lake pegmatite fields, Manitoba. Min. Res. Div. Econ. Geol., Rept. ER80-1, p. 234

Černý, P., Stanĕk, J., Novák, M., Baadsgaard, H., Rieder, M., Ottolini, L., Kavalová, M., Chapman, R., 1995. Geochemical and structural evolution of micas in the Rožná and Dobrá Voda pegmatites, Czech Republic. Mineral. Petrol. 55, 177-201.

Cheilletz, A., Archibald, D.A., Cuney, M., Charoy, B., 1992. ${ }^{40} \mathrm{Ar} /{ }^{39} \mathrm{Ar}$ dating of topazlepidolite Beauvoir leucogranite and Chèdeville sodium-lithium pegmatites (North Massif Central, France). Petrological and geodynamical Meaning. C. R. Acad. Sci. Paris 315, 326-336 (in french).

Cuney, M., Marignac, C., Weisbrod, A., 1992. The Beauvoir topaz-lepidolite albite granite (Massif Central, France); the disseminated magmatic magmatic Sn-Li-Ta-Nb-Be mineralization. Econ. Geol. 87, 1766-1794. doi:10.2113/gsecongeo.87.7.1766

Cuney, M., Alexandrov, P., Le Carlier de Veslud, C., Cheilletz, A., Raimbault, L., Ruffet, G., Scaillet, S., 2002. The timing of W-Sn rare metals mineral deposit formation in the Western Variscan chain in their orogenic stting: the case of the Limousin area (Massif Central, France). Geol. Soc., London, Special Publications 204, 213-228. 
Deveaud, S., Gumiaux, C., Gloaguen, E., Branquet, Y., 2013. Spatial statistical analysis applied to rare-element LCT-type pegmatite fields: an original approach to constrain faults-pegmatites-granites relationships. J. Geosci. 58, p 163-182. doi:10.3190/jgeosci.141

Dill, H.G., 2015. Pegmatites and aplites: Their genetic and applied ore geology. Ore. Geol. Rev. doi: 10.1016/j.oregeorev.2015.02.022.

Flesch, G.D., Anderson, Jr. A.R., Svec, H.J., 1973. A secondary isotopic standard for ${ }^{6} \mathrm{Li} /{ }^{7} \mathrm{Li}$ determinations. Inter. J. Mass. Spectrom. Ion. Proc. 12, 265-272. doi: $10.1016 / 0020-7381(73) 80043-9$

Foord, E.E., Černý, P., Jackson, L.L., Sherman, D.M., Eby, R.K., 1995. Mineralogy and geochemical evolution of micas from miarolitic pegmatites of anorogenic Pikes Peak batholith, Colorado. Mineral. Petrol. 55, 1-26

Hollinger, P., Cuney, M., Friedrich, M., Turpin, L., 1986. Carboniferous age of the Brâme Unit from Saint Sylvestre Peraluminous Granitic Complex (north western edge of French Massif Central) defined by $\mathrm{U} / \mathrm{Pb}$ isotopic data on zircon and monazite. C. R. Acad. Sci. Paris 303, 1309-1312 (in French).

Icenhower, J., London, D., 1995. An experimental study of element partitioning among biotite, muscovite and coexisting peraluminous granitic melt at $200 \mathrm{MPa}\left(\mathrm{H}_{2} \mathrm{O}\right)$. Am. Mineral. 80, 1229-1251. 
Jahn, S., Wunder, B., 2009. Lithium speciation in aqueous fluids at high P and T studied by $a b$ initio molecular dynamics and consequences for $\mathrm{Li}$-isotope fractionation between minerals and fluids. Geochem. Cosmo. Act. 73, 5428-5434.

Jahns, R.H., Burnham, C.W., 1969. Experimental studies of pegmatite genesis. I. A model for the derivation and crystallization of granitic pegmatites. Econ. Geol. 64, 843864.

Jochum, K.P., Willbold, M., Raczek, I., Stoll, B., Herwig, K., 2005. Chemical characterization of the USGS reference glasses GSE-1G, GSC-1G, GSD-1G, GSE-1G, BCR-2G, BHVO-2G and BIR-1G using EPM, ID-TIMS, ID-ICP-MS and LA-ICP-MS. Geostand. Geoanal. Res. 29, 285-302. doi:10.1111/j.1751-908X.2005.tb00901.x

Krienitz, M.-S., Garbe-Schönberg, C.-D., Romer, R.L., Meixner, A., Haase, K.M., Stroncik, N.A., 2012. Llithium isotope variations in Ocean Island Basalts Implications for the development of mantle heterogeneity. J. Petrol. 53 (11), 2333-2347.

Li, J., Huang, X.L., He, P.L., Li, W.X., Yu, Y., Chen, L.L., 2015. In situ analyses of micas in the Yashan granite, South China: Constraints on magmatic and hydrothermal evolutions of W and Ta-Nb bearing granites. Ore. Geol. Rev. 65, 793-810

Linnen, R.L., 1998. The solubility of Nb-Ta-Zr-Hf-W in granitic melts with $\mathrm{Li}$ and $\mathrm{Li}+\mathrm{F}$; constraints for mineralization in rare metal granites and pegmatites. Econ. Geol. 93, 1013-1025. doi:10.2113/gsecongeo.93.7.1013 
Linnen, R.L., Van Litchervelde, M., Černý, P., 2012. Granitic pegmatites as sources of strategic metals. Elements 8, 275-280.

London, D., 2005. Granitic pegmatites: an assessment of current concepts and directions for the future. Lithos 80, 281-303.

London, D., 2008. Pegmatites. Can. Mineral. Special Publication 10, p. 363.

London, D., Morgan VI, G.B., 2012. The pegmatite puzzle. Elements 8, 263-268.

London, D., 2014a. Reply to Thomas and Davidson on "a petrologic assessment of internal zonation in granitic pegmatites" (London 2014b). Lithos 212-215, 469-484.

London, D., 2014b. A petrologic assessment of internal zonation in granitic pegmatites. Lithos 187-187, 74-104.

Magna, T., Janoušek, V., Kohút, M., Wiechert, U., 2010. Fingerprinting sources of orogenic plutonic rocks from Variscan belt with lithium isotopes and possible link to subduction-related origin of some A-type granites. Chem. Geol. 274, 94-107. doi:10.1016/j.chemgeo.2010.03.020

Maloney, J.S., Nabelek, P.I., Sirbescu, M.L.C., Halama, R., 2008. Lithium and its isotopes in tourmaline as indicators of the crystallization process in the San Diego 
County pegmatites, California, USA. Eur. J. Mineral. 20, 905-916. doi:10.1127/0935$1221 / 2008 / 0020-1823$

Marchal, K.L., Simmons, W.B., Falster, A.U., Webber, K.L., 2014. Geochemistry, mineralogy, and evolution of Li-Al micas and feldspars from the Mount mica pegmatite, Maine, USA. Can. Mineral. 52, 221-233.

Marignac, C., Cuney, M., 1999. Ore deposits of the French Massif Central: insight into the metallogenesis of the Variscan collision belt. Miner. Deposita 34, 472-504. doi:10.1007/s001260050216

Melleton, J., Gloaguen, E., Frei, D., Novák, M., Breiter, K., 2012. How are the emplacement of rare-element pegmatites, regional metamorphism and magmatism interrelated in the Moldanubian domain of the Variscan Bohemian Massif, Czech Republic? Can. Mineral. 50 (6), 1751-1773.

Melleton, J., Gloaguen, E., Frei, D., Lima, A., 2011. U-Pb dating of columbite-tantalite from Variscan rare-elements granites and pegmatites. In Goldschmidt 75 (3), pp. 1452.

Martins, T., Roda-Robles, E., Lima, A., De Parseval, P., 2012. Geochemistry and evolution of micas in the Barroso-Alvão pegmatite field, northern Portugal. Can. Mineral. $50,1117-1119$. 
Millot, R., Guerrot, C., Vigier, N., 2004. Accurate and high-precision measurement of lithium isotopes in two reference materials by MC-ICP-MS. Geostand. Geoanal. Res. 28, 153-159. doi:10.1111/j.1751-908X.2004.tb01052.x

Millot, R., Scaillet, B., Sanjuan, B., 2010. Lithium isotopes in island arc geothermal systems: Guadeloupe, Martinique (French West Indies) and experimental approach. Geochim. Cosmochim. Acta 74 (6), 1852-1871.

James, R.H., Palmer, M.R., 2000. The lithium isotope composition of internal rock standards. Chem. Geol. 166, 319-326.

Parkinson, I.J., Hammond, S.J., James, R.H., Rogers, N.W., 2007. High-temperature lithium isotope fractionation: Insights from lithium isotope diffusion in magmatic systems. Earth Planet. Sc. Lett. 257, 609-621. doi:10.1016/j.epsl.2007.03.023

Patureau, J., 1987. Study of Monts d'Ambazac pegmatites (Margnac, Le Mas Barbu), (Haute-Vienne). Unpublished PhD. Thesis, University of Paul Sabatier, Toulouse (in french).

Pearce, N.J.G., Perkins, W.T., Westgate, J.A., Gorton, M.P., Jackson, S.E., Neal, C.R., Chenery, S.P., 1997. A compilation of new and published major and trace element data for NIST SRM 610 and NIST SRM 612 glass reference materials. Geostand. Geoanal. Res. 21, 115-144. doi:10.1111/j.1751-908X.1997.tb00538.x 
Raimbault, L., 1998. Composition of complex lepidolite-type granitic pegmatites and of constituent columbite-tantalite, Chédeville, Massif Central, France. Can. Mineral. 36, 563-583.

Raimbault, L., Burnol, L., 1998. The Richemont rhyolite dike, Massif Central, France; a subvolcanic equivalent of rare-metal granites. Can. Mineral. 36, 265-282.

Roda. E., Presquera, A., Velasco, F., 1995. Micas of the muscovite-lepidolite series from the Fregeneda pegmatites (Salamanca, Spain). Mineral. Petrol. 55, 145-157.

Roda-Robles, E., Presquera, A., Gil-Crespo, P.P., Torres-Ruiz, J., DeParseval, P., 2006. Mineralogy and geochemistry of micas from the Pinilla de Fermoselle pegmatite (Zamora, Spain). Europ. Jour. Mineral. 19, 369-377.

Romer, R.L., Meixner, A., Förster, H.J., 2014. Lithium and boron in late-orogenic granites. Isotopic fingerprints for the source of crustal melts? Geochim. Cosmochim. Acta. 131, 98-114. doi:10.1016/j.gca.2014.01.018

Simmons, W.B., Foorf, E.E., Falster, A.U., King, V.T., 1995. Evidence for an anatectic origin of granitic pegmatites, western Maine, USA. Geol. Soc. Am., abstracts with programs $27,411$.

Simmons, W.B., Webber, K.L., 2008. Pegmatite genesis: state of the art. Eur. J. Mineral. 20, 421-438. 
Teng, F.Z., McDonough, W.F., Rudnick, R.L., Dalpé, C., Tomascak, P.B., Chappell, B.W., Gao, S., 2004. Lithium isotopic composition and concentration of the upper continental crust. Geochim. Cosmochim. Acta. 68, 4167-4178. doi:10.1016/j.gca.2004.03.031

Teng, F.Z., McDonough, W.F., Rudnick, R.L., Walker, R.J., Sirbescu, M.L.C., 2006a. Lithium isotopic systematics of granites and pegmatites from the Black Hills, South Dakota. Am. Mineral. 91, 1488-1498. doi:10.2138/am.2006.2083

Teng, F.Z., McDonough, W.F., Rudnick, R.L., Walker, R.J., 2006b. Diffusion-driven extreme lithium isotopic fractionation in country rocks of the Tin Mountain pegmatite. Earth Planet. Sc. Lett. 243, 701-710. doi:10.2138/am.2006.2083

Thomas, R., Davidson, P., 2014. Comment on" A petrological assessment of internal zonation in granitic pegmatites" by David London (2014b). Lithos 212-215, 462-468.

Tischendorf, G., Gottesmann, B., Foerster, H.J., Trumbull, R.B., 1997. On Li-bearing micas; estimating $\mathrm{Li}$ from electron microprobeanalyses and improved diagram for graphical representation. Mineral. Mag. 61, 809-834.

Tomascak, P.B., Lynton, S.J., Walker, R.J., Krogstad, E.J., 1995. Li isotope geochemistry of the Tin Mountain pegmatite, Black Hills, South Dakota. In: Brown, M., Piccoli, P.M., (Eds.), US Geol. Surv. Circ. 1129, pp. 151-152. 
Tomascak, P.B., Tera, F., Helz, R.T., Walker, R.J., 1999. The absence of lithium isotope fractionation during basalt differentiation: New measurements by multicollector sector ICP-MS. Geochim. Cosmochim. Acta. 63, 907-910.

Tomascak, P.B., 2004. Developments in the understanding and application of lithium isotopes in the earth and planetary sciences. Rev. Mineral. Geochem. 55, 153-195. doi:10.2138/gsrmg.55.1.153

Trueman, D.L., Černý, P., 1982. Exploration for rare-element granitic pegmatites. In Granitic Pegmatites in Science and Industry (P. Černý, ed.). Mineral. Assoc. Canada, Short Course Handbook 8, pp. 463-494.

Wenger, M., Armbruster, T., 1991. Crystal chemistry of lithium: oxygen coordination and bonding. Eur. J. Mineral. 3, 387-399.

Whitney, D.L., Evans, B.W., 2010. Abbreviations for names of rock-forming minerals. Am. Mineral. 95, 185-185.

Wunder, B., Meixner, A., Romer, R.L., Feenstra, A., Schettler, G., Heinrich, W., 2007. Lithium isotope fractionation between Li-bearing staurolite, Li mica and aqueous fluids: An experimental study. Chem. Geol. 238, 277-290. doi: 10.1016/j.epsl.2007.03.023 
Wunder, B, Meixner, A, Romer, R.L, Jahn, S., 2011. Li-isotope fractionation between silicates and fluids: Pressure dependence and influence of the bounding environment. Eur. J. Miner. 23, 333-342. doi:10.1127/0935-1221/2011/0023-2095 


\section{Figure captions}

FIG. 1: $\delta^{7} \mathrm{Li}$ values (\%) available in the literature and measured on whole rocks and $\mathrm{Li}$ micas from granite-pegmatite systems. Error bars represent the $\delta^{7} \mathrm{Li}(\%)$ dispersion obtained for each pegmatite and/or granite.

FIG. 2: Geological map of the rare-element Monts d'Ambazac pegmatite field (MAPF), modified from Deveaud et al. (2013). Each pegmatitic dike sampled during this study is located on the map. Pegmatites are grouped according to their degree of differentiation, from Type II to Type VI pegmatite.

FIG. 3: A) Example of Type II pegmatitic dike. B) Skeletal texture of biotite and quartz crystals observed in intermediate unit of some Type III pegmatites. C) Extensive biotitization at the exocontact of a Type IV pegmatitic intrusion. Discontinuous layered aplite is visible above this metasomatic contact. D) Quartz core showing centimetric beryl crystals in the inner portion of a Type IV pegmatite. E) Disrupted layered aplite in

external portion of a Type $\mathrm{V}$ pegmatite. F) Blocky zone in Type VI pegmatite with centimetric petalite crystals enclosed in a layered albite-lepidolite-quartz matrix. Mineral abbreviations according to Whitney and Evans (2010).

FIG. 4: Microscopic cross-polarized light observations of various micas from MAPF. (A) Apatite and zircon inclusions in biotite from Saint-Sylvestre granite. (B) Primary type IV biotite. (C) Primary generation of muscovite in Type V pegmatite. (D) Pervasive sericitic alteration in k-feldspar crystals from Type III pegmatite. (E) Massive quartz-lepidolite crystals observed only in Type VI pegmatite. (F) Handpicked fresh muscovite from Type IV pegmatite. Mineral abbreviations according to Whitney and Evans (2010). 
FIG. 5: Compositional fields of natural trioctahedral and dioctahedral micas plotted on a diagram of $[\mathrm{Mg}-\mathrm{Li}]$ vs. $\left[\mathrm{Fe}_{\text {tot }}+\mathrm{Mn}+\mathrm{Ti}-\mathrm{Al} \mathrm{lv}_{\mathrm{l}}\right]$ after Tischendorf et al. (1997). Major elements and $\mathrm{Li}$ content (ppm) obtained on separated mica mounts by CAMECA microprobe (ISTO, Orléans) and LA-ICP-MS (LMV, Clermont-Ferrand), respectively.

FIG. 6: Structural components of biotite: $\mathrm{Al}_{\mathrm{IV}}$ vs. $\mathrm{Fe} /(\mathrm{Fe}+\mathrm{Mg}), \mathrm{Al}_{\mathrm{v} I}$ vs. $\mathrm{Fe} /(\mathrm{Fe}+\mathrm{Mg}), \mathrm{Ti}^{4+}$ vs. $\mathrm{Fe} /(\mathrm{Fe}+\mathrm{Mg})$, and $\mathrm{Mn}^{2+}$ vs. $\mathrm{Fe} /(\mathrm{Fe}+\mathrm{Mg})$ for each pegmatite type from MAPF, obtained by CAMECA microprobe (ISTO, Orléans) on separated mica mounts.

FIG. 7: Li content of each biotite and muscovite solution plotted against $\mathrm{K} / \mathrm{Rb}$ ratio, obtained by ICP-AES (Laboratory Division, BRGM). Elemental $\mathrm{K} / \mathrm{Rb}$ ratio is used as marker of pegmatite-forming melt differentiation.

FIG. 8: Trace-element composition of white and dark mica solutions ( $\mathrm{Li}, \mathrm{Cs}, \mathrm{Be}$ and $\mathrm{Sn}$, in $\mathrm{ppm}$ ) as a function of the $\mathrm{K} / \mathrm{Rb}$ ratio's evolution.

FIG. 9: $\delta^{7} \mathrm{Li}$ values $(\%)$ of biotite (green) and muscovite (red) plotted against Li content (ppm) of each aliquot. Pegmatite types from less evolved (Type II) to more evolved (Type V) are distinguished.

FIG. 10: Evolution of $\delta^{7} \mathrm{Li}$ content in dark and white mica as function of rare-element content (in ppm) for $\mathrm{Be}, \mathrm{Cs}, \mathrm{Rb}$, and $\mathrm{Nb} / \mathrm{Ta}$ ratio.

FIG. 11: $\delta^{7} \mathrm{Li}$ values (\%o) versus $\mathrm{Li}$ content $(\mathrm{ppm})$ measured on whole rocks and separated Li micas from granite-pegmatite systems given in electronic supplementary material. $\delta^{7} \mathrm{Li}$ values $(\% \circ)$ from the present study are represented by black squares. $\delta^{7} \mathrm{Li}$ 
values $(\%)$ measured on lepidolite and granite biotite are distinguished from the other pegmatite micas. 


\section{Table captions}

Table 1: Major and trace element compositions of biotite, muscovite and lepidolite crystals sampled for this study, measured by SX5-Cameca electron microprobe. Geochemical compositions were obtained in situ to test the homogeneity of chemical composition of micas analyzed by Neptune MC-ICP-MS. Li content was obtained by LAICP-MS Agilent 7500 series.

Table 2: Major and trace element compositions of mica aliquots used for $\mathrm{Li}$ isotope analyses, measured by ICP-AES.

Table 3: Measurements of $\delta^{7} \mathrm{Li}$ values (\%o) in the MAPF micas associated with $\mathrm{Li}$ content. 


\section{Electronic Supplementary Material}

Table 4: $\delta^{7} \mathrm{Li}$ values $(\%)$ and [Li] measured on whole-rock and separated micas, from the literature. Sample name, age and location are also shown. 


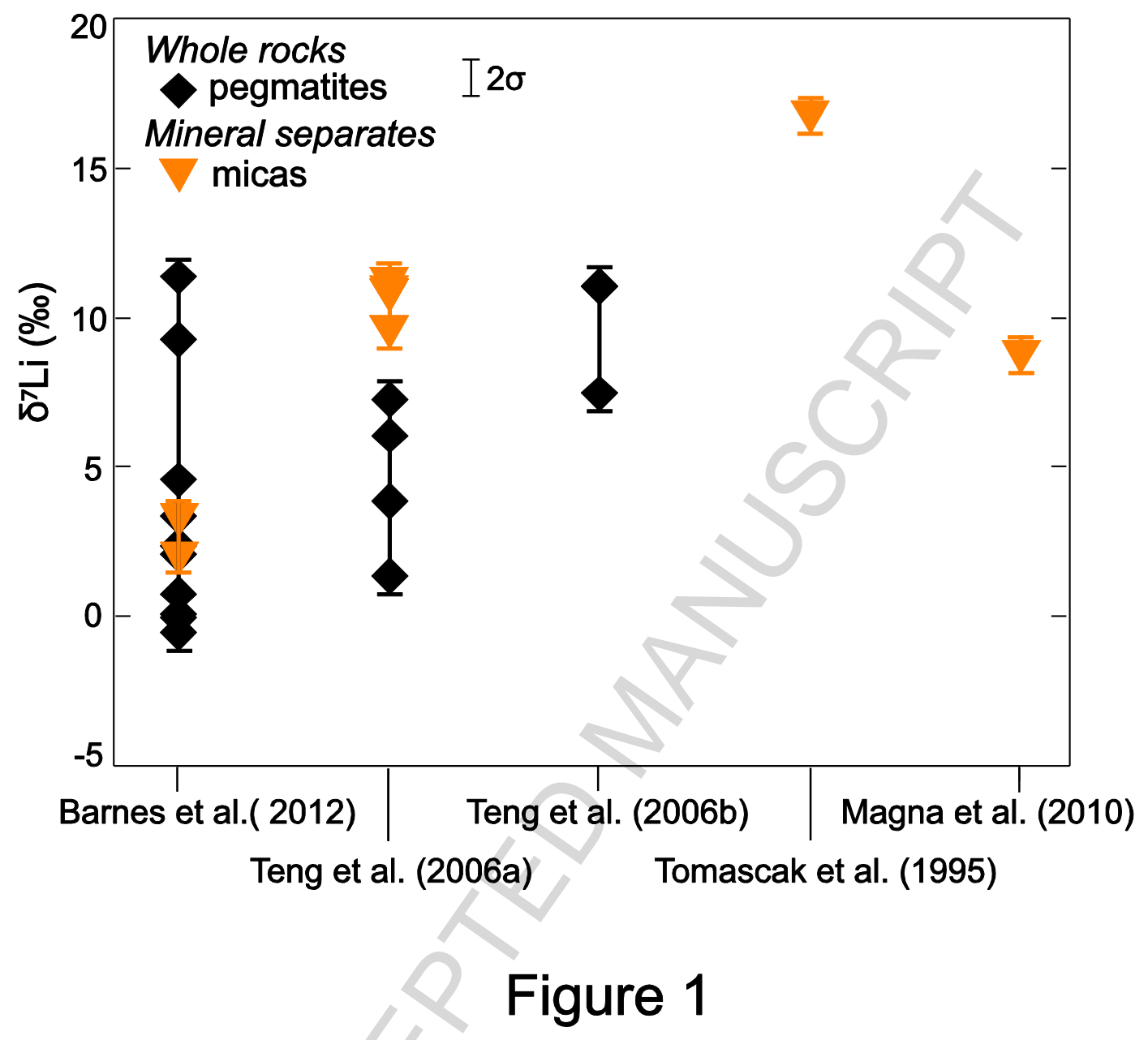




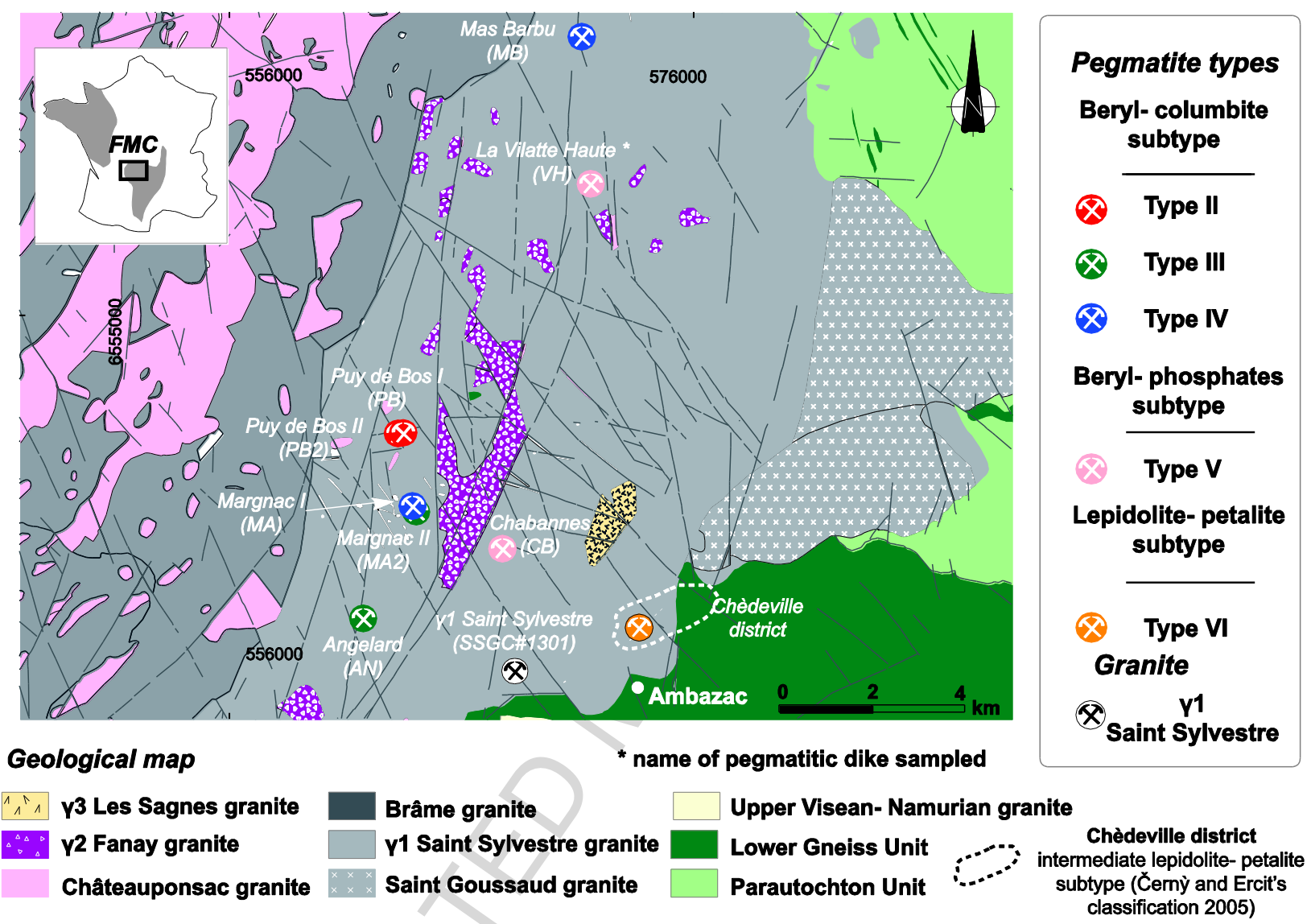

\section{Figure 2}



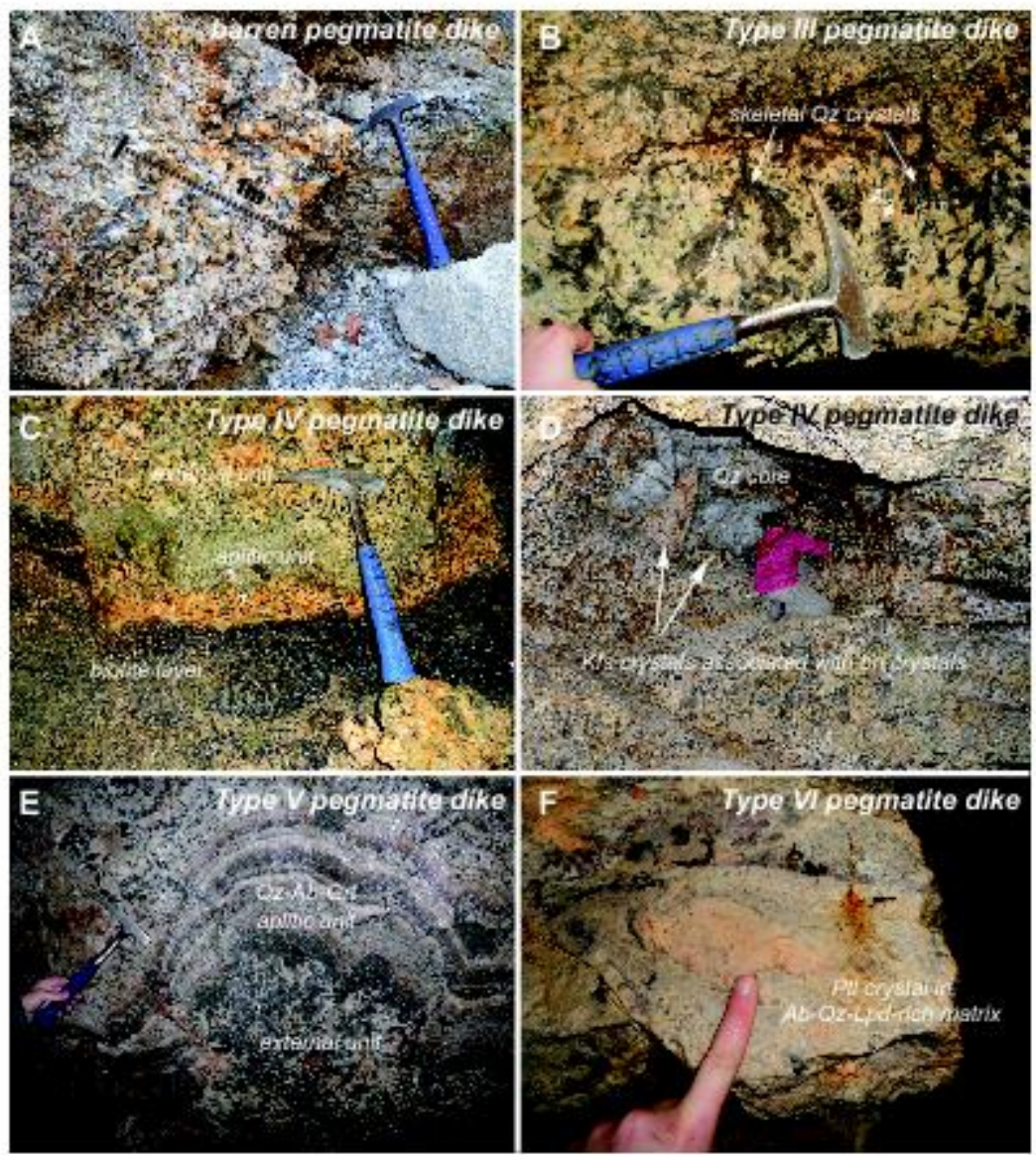

Figure 3 

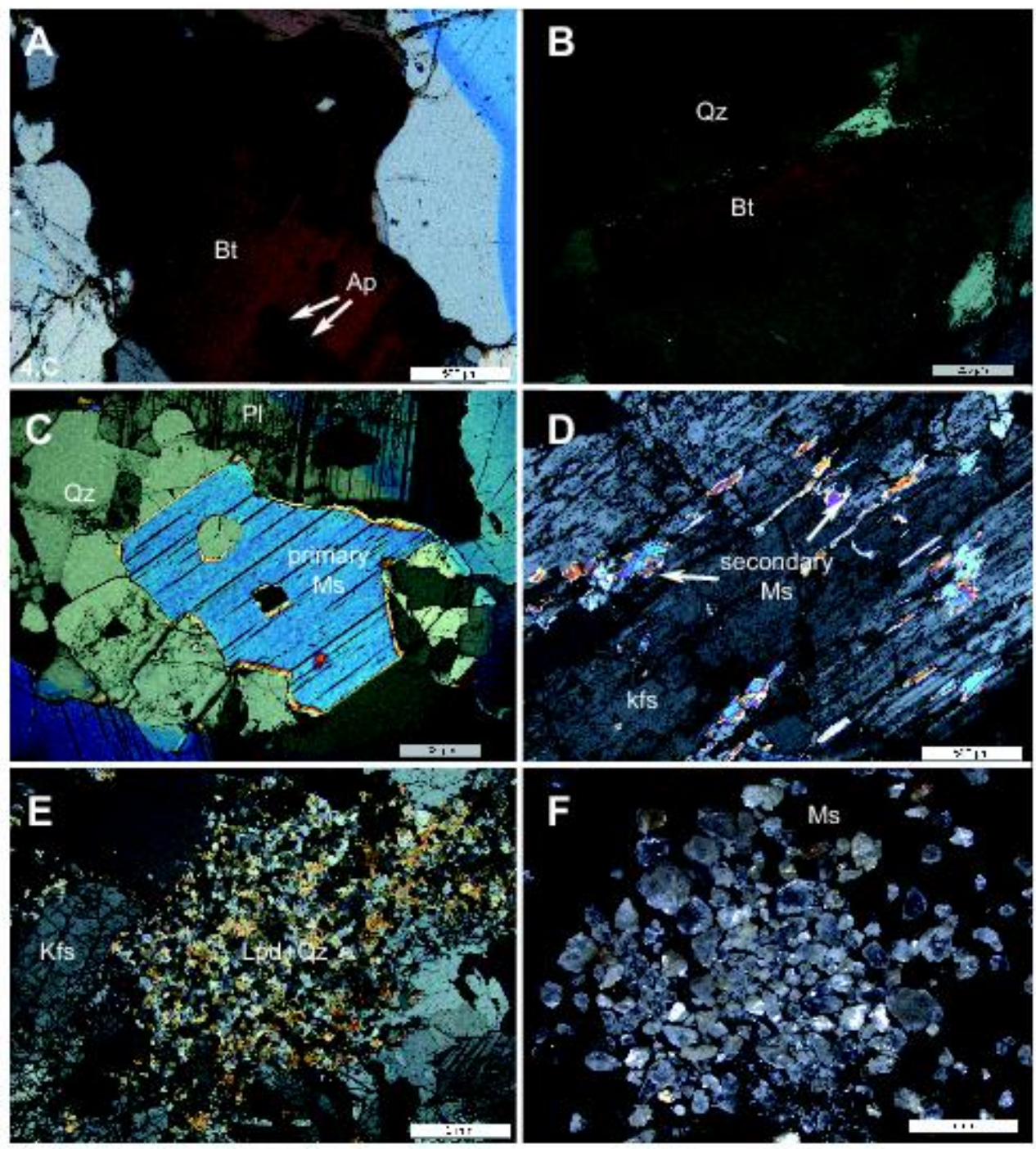

Figure 4 


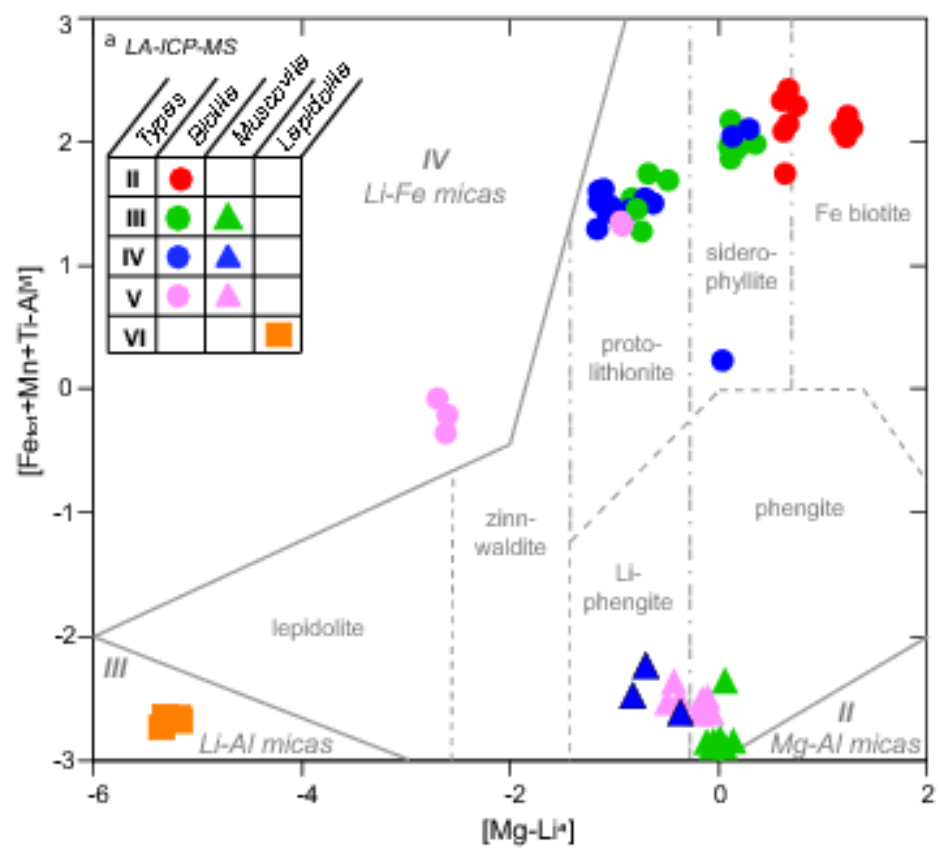

Figure 5 

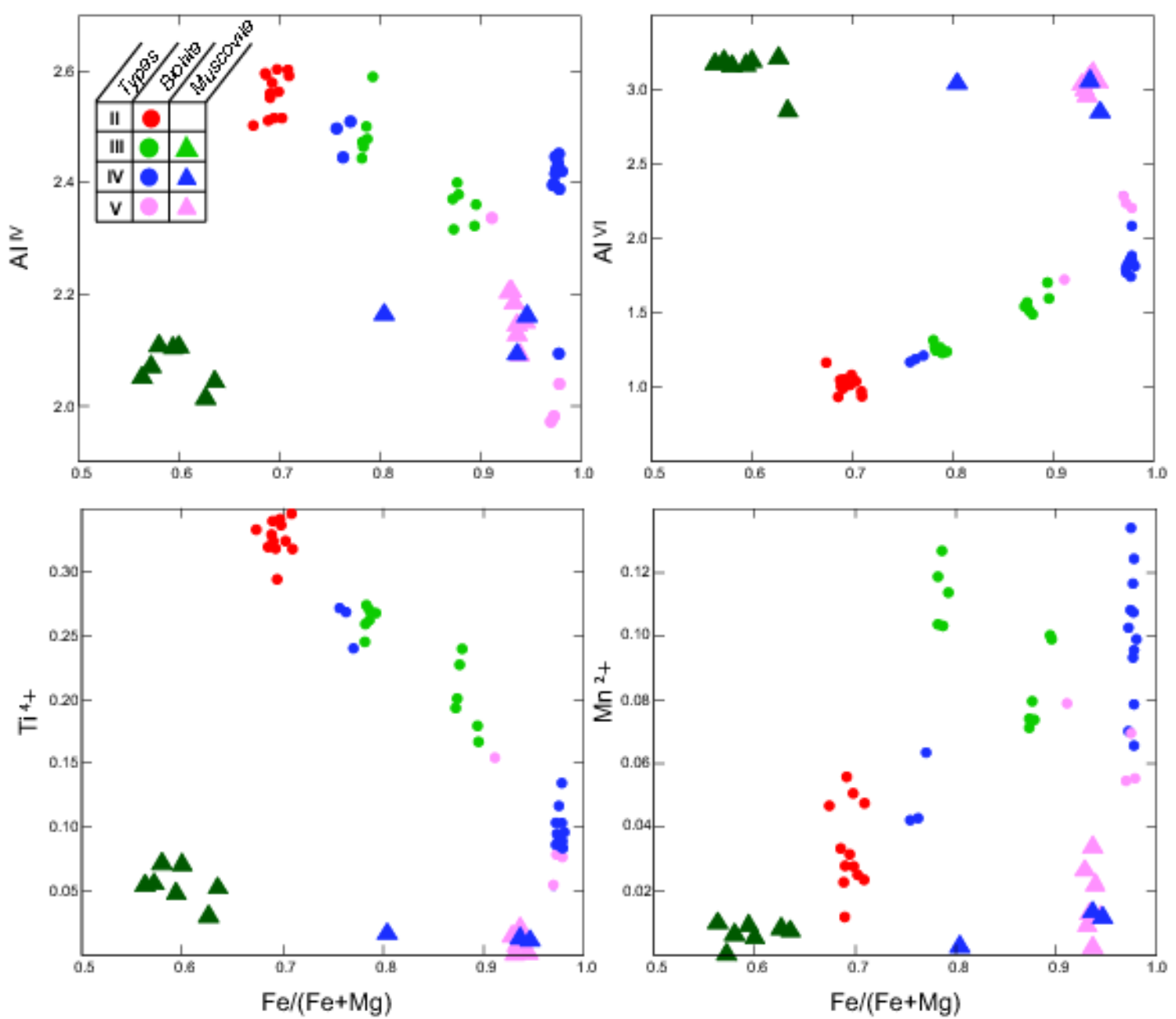

Figure 6 


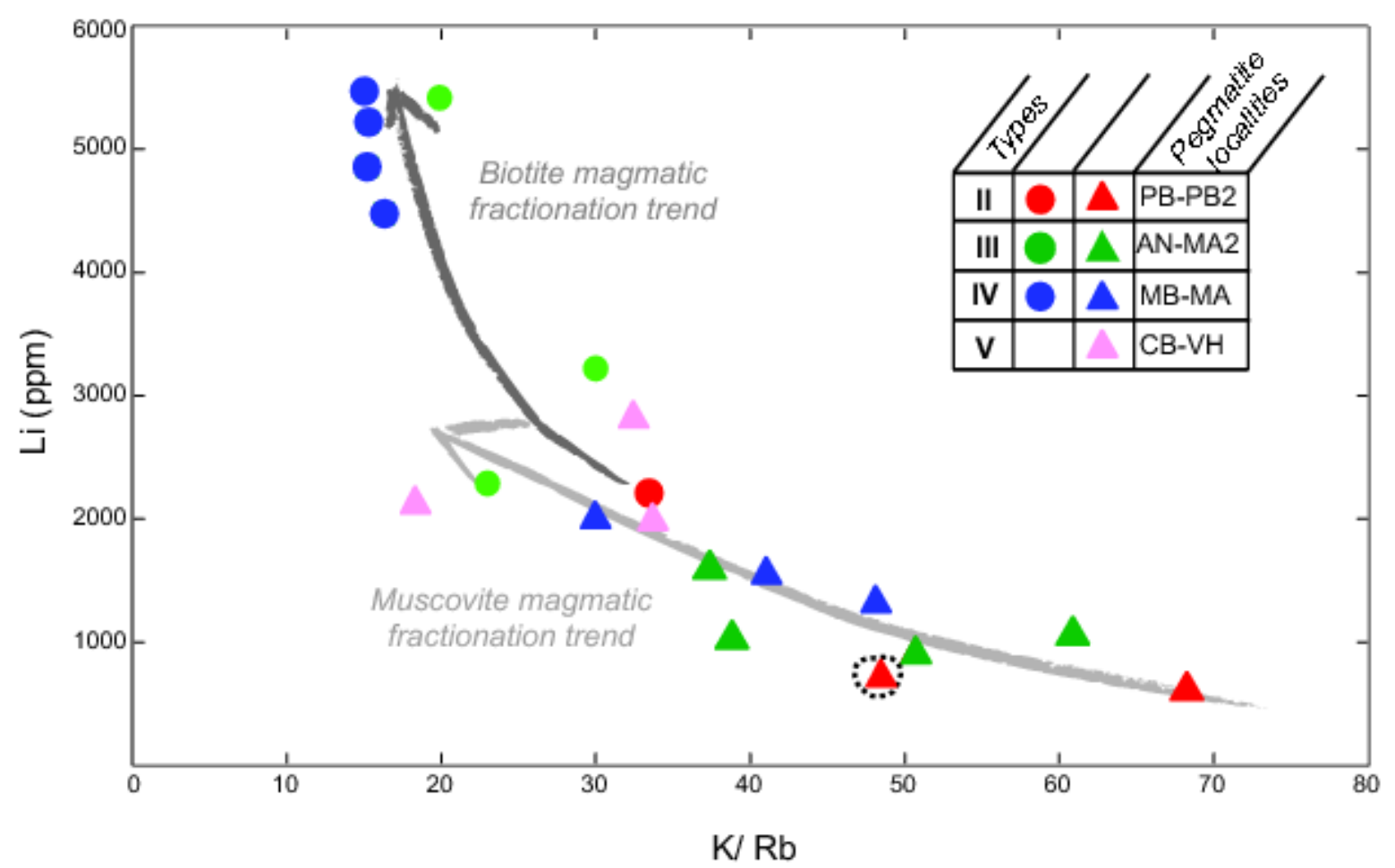

Figure 7 

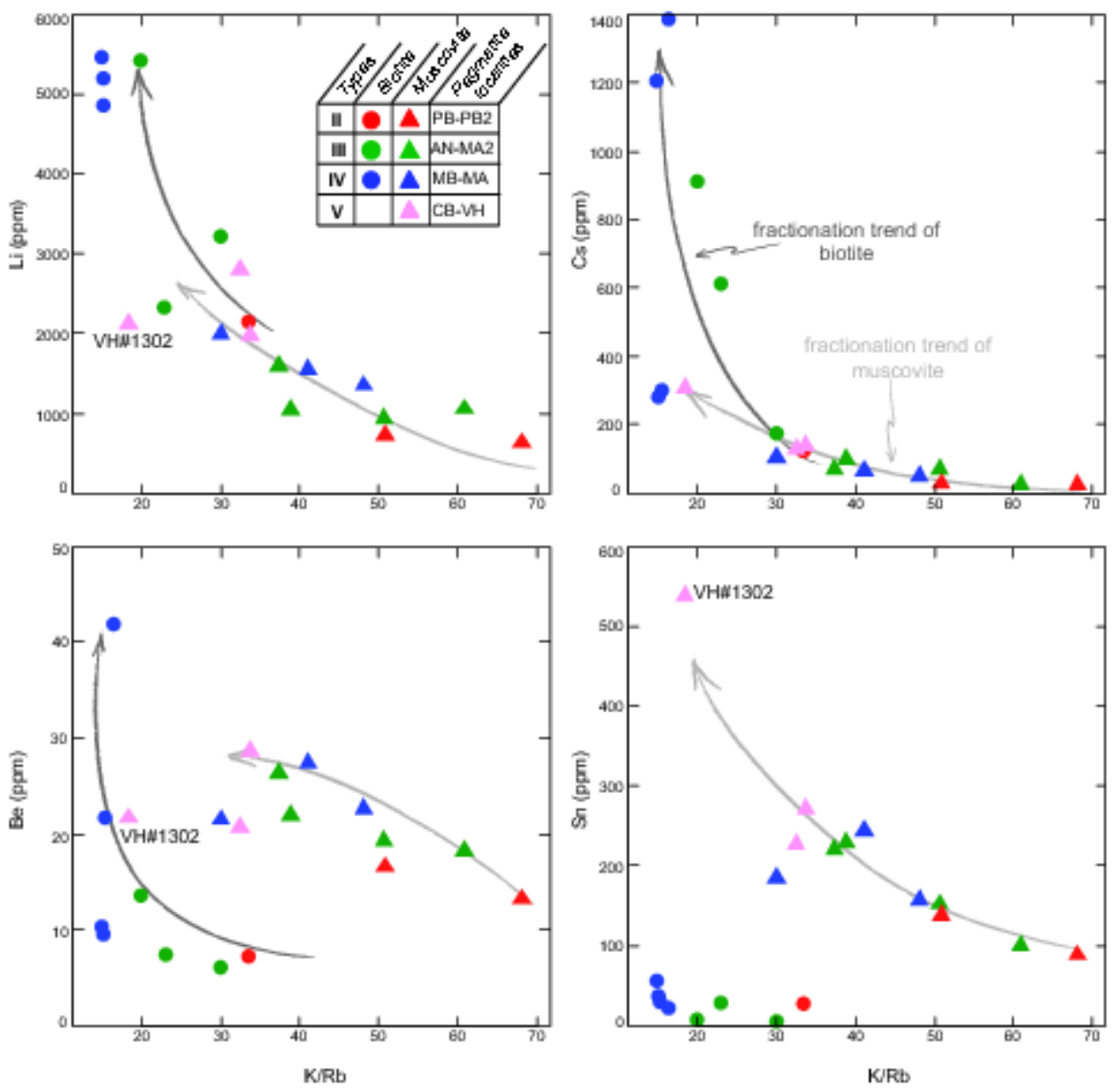

Figure 8 


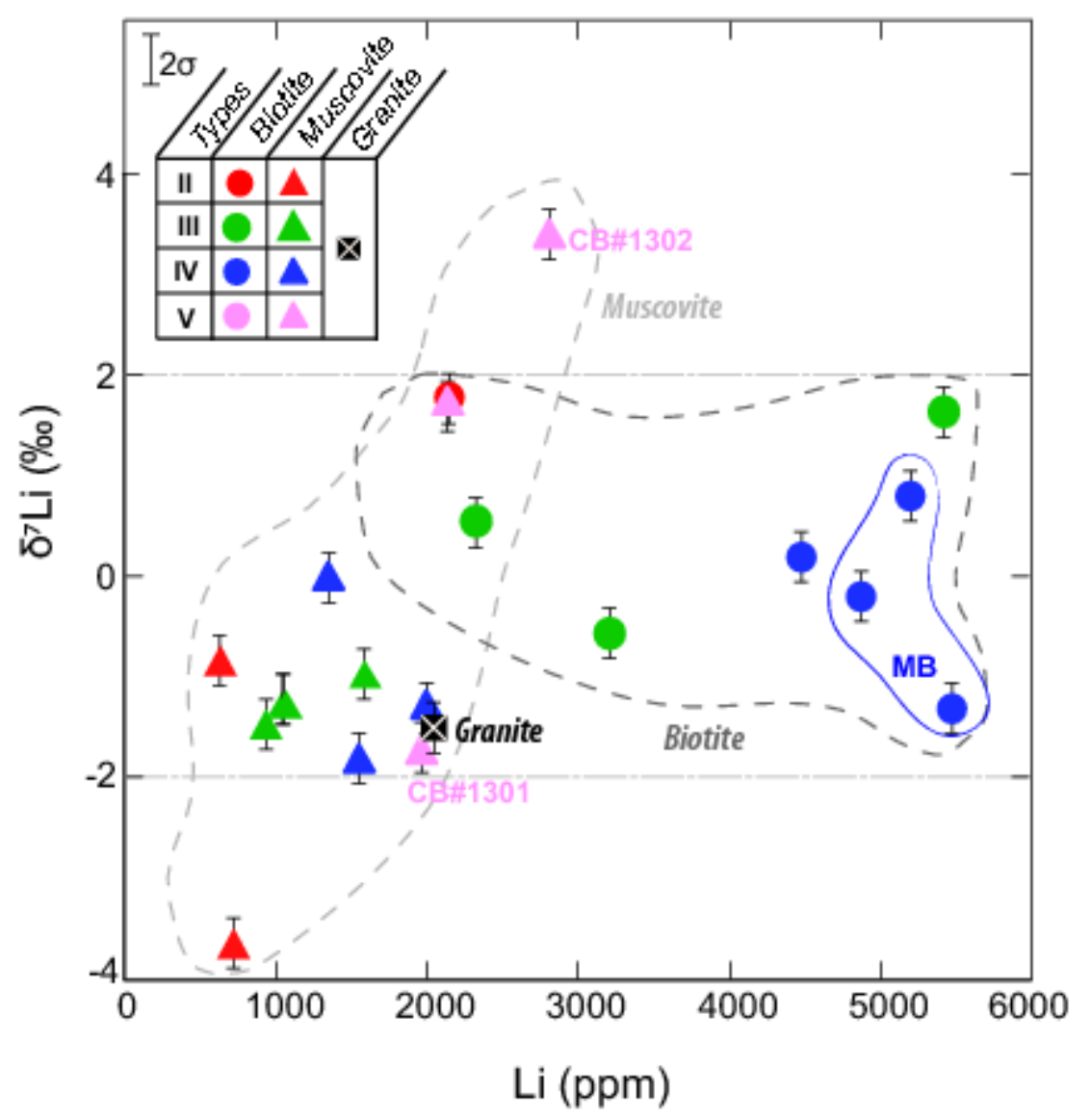

Figure 9 

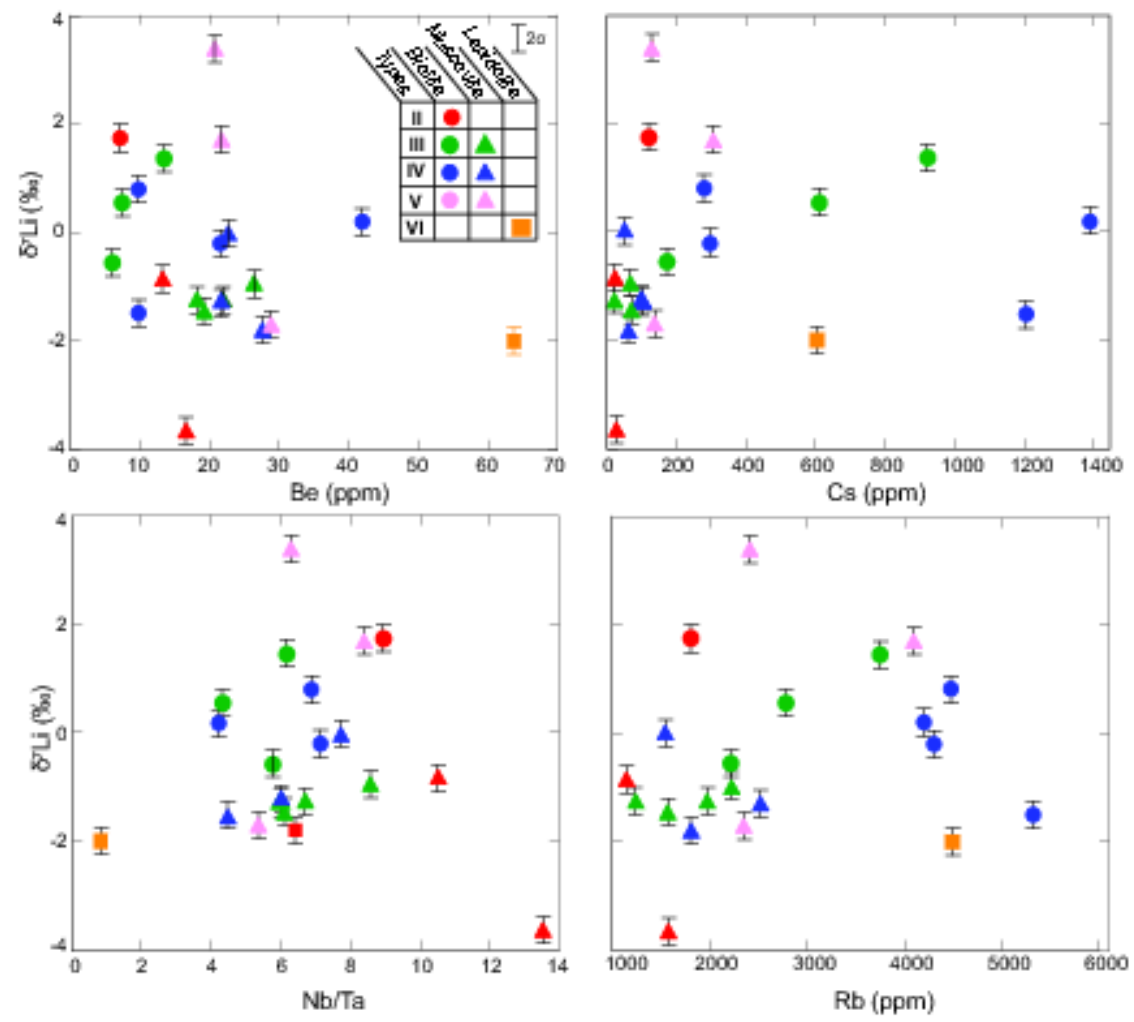

Figure 10 


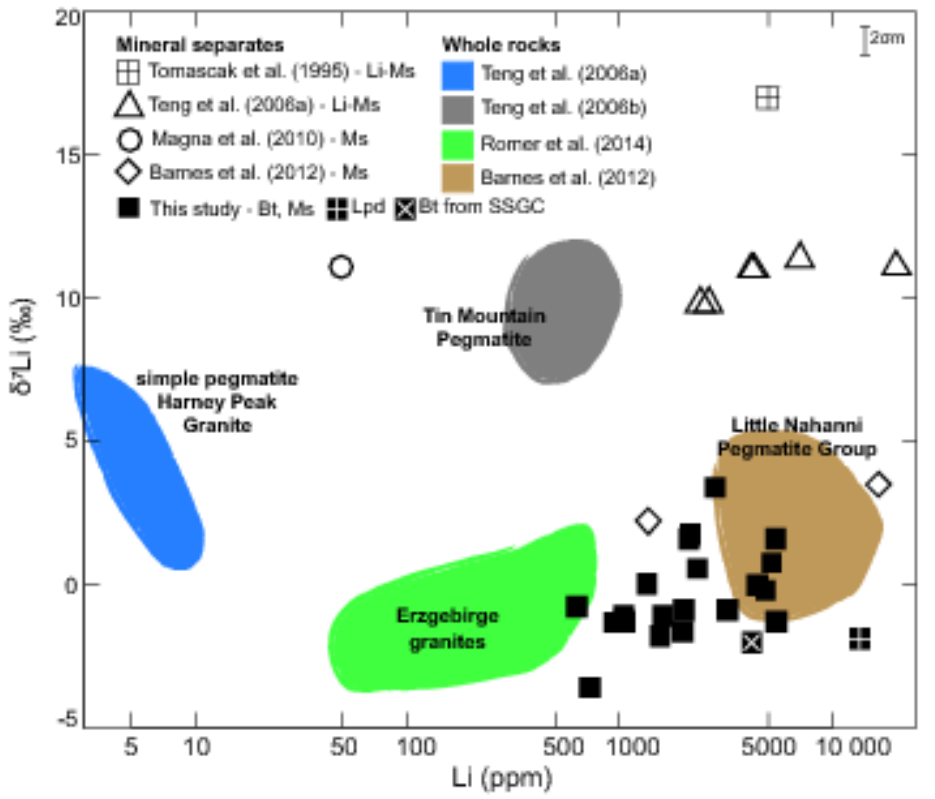

Figure 11

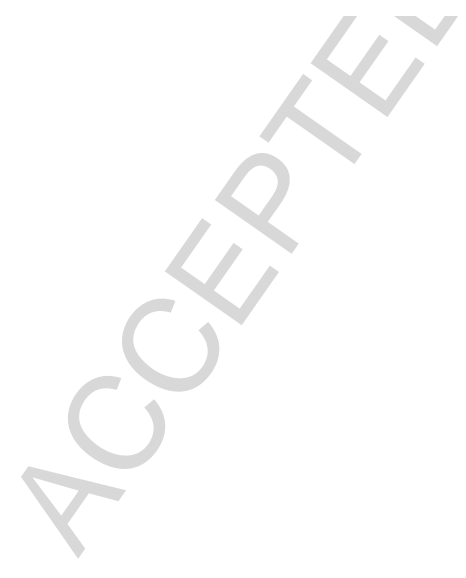




\section{Table 1}

\begin{tabular}{|c|c|c|c|c|c|c|c|c|c|c|}
\hline Mineral & Bt & $\mathrm{Bt}$ & Bt & $\mathrm{Bt}$ & $\mathrm{Bt}$ & Bt & Bt & Lpd & Ms & Ms \\
\hline Pegmatite type & II & III & IV & IV & III & IV & v & VI & III & III \\
\hline $\mathrm{n}$ points & 12 & 6 & 8 & 5 & 6 & 6 & 4 & 4 & 1 & 2 \\
\hline $\mathrm{SiO}_{2}$ & 34.64 & 35.86 & 34.73 & 34.71 & 34.74 & 35.16 & 38.72 & 48.83 & 45.48 & 44.77 \\
\hline $\mathrm{TiO}_{2}$ & 2.78 & 1.70 & 0.78 & 0.78 & 2.21 & 1.55 & 0.79 & 0.04 & 0.30 & 0.71 \\
\hline $\mathrm{Al}_{2} \mathrm{O}_{3}$ & 19.35 & 21.18 & 22.47 & 22.35 & 20.08 & 20.93 & 23.29 & 26.89 & 33.81 & 33.91 \\
\hline $\mathrm{FeO}$ & 21.37 & 21.48 & 23.10 & 22.86 & 21.89 & 21.53 & 16.56 & 0.05 & 2.19 & 1.94 \\
\hline $\mathrm{MgO}$ & 5.28 & 1.62 & 0.32 & 0.31 & 3.35 & 2.08 & 0.47 & 0.02 & 0.73 & 0.76 \\
\hline $\mathrm{MnO}$ & 0.25 & 0.62 & 0.80 & 0.73 & 0.85 & 0.47 & 0.50 & 0.45 & 0.07 & 0.05 \\
\hline $\mathrm{CaO}$ & 0.00 & 0.01 & 0.00 & 0.00 & 0.00 & 0.00 & 0.00 & 0.03 & 0.00 & 0.00 \\
\hline $\mathrm{Na}_{2} \mathrm{O}$ & 0.13 & 0.20 & 0.19 & 0.15 & 0.11 & 0.16 & 0.17 & 0.36 & 0.72 & 0.60 \\
\hline $\mathrm{K}_{2} \mathrm{O}$ & 8.79 & 8.80 & 8.61 & 8.63 & 8.73 & 8.86 & 9.22 & 10.29 & 9.34 & 9.29 \\
\hline $\mathrm{F}$ & 1.83 & 3.50 & 3.29 & 3.52 & 2.43 & 3.45 & 5.22 & 8.18 & 1.88 & 1.26 \\
\hline $\mathrm{Cl}$ & 0.04 & 0.01 & 0.02 & 0.02 & 0.02 & 0.02 & 0.01 & 0.04 & 0.00 & 0.01 \\
\hline Total & 94.46 & 94.97 & 94.31 & 94.07 & 94.41 & 94.19 & 94.94 & 95.18 & 94.53 & 93.30 \\
\hline $\mathrm{Li}_{2} \mathrm{O}^{\mathrm{a}}$ & 0.35 & 0.71 & 0.38 & 0.37 & 0.38 & 0.50 & 1.53 & 4.45 & 3.49 & 3.28 \\
\hline $\mathrm{OH}$ & 0.75 & 0.06 & 0.07 & 0.01 & 0.47 & 0.18 & 0.00 & 0.84 & 0.85 & 0.90 \\
\hline Total & 95.57 & 95.74 & 94.75 & 94.45 & 95.26 & 94.88 & 96.48 & 100.48 & 98.87 & 97.48 \\
\hline $\mathrm{O}=\mathrm{F}$ & 0.41 & 0.79 & 0.74 & 0.79 & 0.55 & 0.78 & 1.18 & 3.45 & 0.16 & 0.11 \\
\hline $\mathrm{O}=\mathrm{Cl}$ & 0.00 & 0.00 & 0.00 & 0.00 & 0.00 & 0.00 & 0.00 & 0.01 & 0.00 & 0.01 \\
\hline $\begin{array}{l}\text { Total } \\
\text { Site- } T\end{array}$ & 95.98 & 96.53 & 95.49 & 95.25 & 95.81 & 95.66 & 97.65 & 103.93 & 99.03 & 97.60 \\
\hline $\mathrm{Si}$ & 5.44 & 5.64 & 5.57 & 5.59 & 5.51 & 5.60 & 5.92 & 6.43 & 5.99 & 5.89 \\
\hline$A I^{I V}$ & 2.56 & 2.36 & 2.43 & 2.41 & 2.49 & 2.40 & 2.08 & 1.57 & 2.01 & 2.11 \\
\hline $\begin{array}{c}\boldsymbol{\Sigma}(\mathbf{S i}, \mathbf{A l}) \\
\text { Site-M }\end{array}$ & 8.00 & 8.00 & 8.00 & 8.00 & 8.00 & 8.00 & 8.00 & 8.00 & 8.00 & 8.00 \\
\hline $\mathrm{Ti}$ & 0.33 & 0.20 & 0.09 & 0.09 & 0.26 & 0.19 & 0.09 & 0.00 & 0.03 & 0.07 \\
\hline $\mathrm{Al}^{\mathrm{VI}}$ & 1.02 & 1.57 & 1.81 & 1.83 & 1.26 & 1.54 & 2.11 & 2.74 & 3.21 & 3.17 \\
\hline $\mathrm{Fe}_{\text {total }}$ & 2.81 & 2.83 & 3.10 & 3.08 & 2.90 & 2.88 & 2.13 & 0.01 & 0.24 & 0.21 \\
\hline $\mathrm{Mg}$ & 1.24 & 0.38 & 0.08 & 0.07 & 0.79 & 0.49 & 0.11 & 0.00 & 0.14 & 0.15 \\
\hline $\mathrm{Mn}$ & 0.03 & 0.08 & 0.11 & 0.10 & 0.11 & 0.06 & 0.06 & 0.05 & 0.01 & 0.01 \\
\hline $\mathrm{Li}$ & 0.22 & 0.44 & 0.24 & 0.24 & 0.24 & 0.32 & 0.94 & 3.41 & 0.78 & 0.52 \\
\hline$\Sigma(\mathrm{Al}, \mathrm{Fe}, \mathrm{Mg}, \mathrm{Ti})$ & 5.39 & 4.97 & 5.08 & 5.07 & 5.22 & 5.10 & 4.44 & 2.76 & 3.62 & 3.61 \\
\hline $\begin{array}{l}\Sigma \mathrm{Al}_{\text {total }} \\
\text { Site-A }\end{array}$ & 3.58 & 3.93 & 4.25 & 4.24 & 3.75 & 3.93 & 4.19 & 4.31 & 5.22 & 5.28 \\
\hline $\mathrm{Ca}$ & 0.00 & 0.00 & 0.00 & 0.00 & 0.00 & 0.00 & 0.00 & 0.00 & 0.00 & 0.00 \\
\hline $\mathrm{Na}$ & 0.04 & 0.06 & 0.06 & 0.05 & 0.03 & 0.05 & 0.05 & 0.09 & 0.18 & 0.15 \\
\hline $\mathrm{K}$ & 1.76 & 1.77 & 1.76 & 1.77 & 1.77 & 1.80 & 1.80 & 1.73 & 1.57 & 1.56 \\
\hline $\begin{array}{c}\boldsymbol{\Sigma}(\mathbf{C a}, \mathbf{N a}, \mathbf{K}) \\
\text { Site- } \mathrm{OH}\end{array}$ & 1.80 & 1.83 & 1.82 & 1.82 & 1.80 & 1.85 & 1.85 & 1.82 & 1.75 & 1.71 \\
\hline $\mathrm{F}$ & 0.91 & 1.74 & 1.67 & 1.79 & 1.22 & 1.73 & 2.51 & 0.01 & 0.00 & 0.00 \\
\hline $\mathrm{Cl}$ & 0.01 & 0.00 & 0.00 & 0.01 & 0.00 & 0.00 & 0.00 & 1.18 & 0.92 & 0.87 \\
\hline $\mathrm{OH}$ & 1.08 & 0.26 & 0.33 & 0.20 & 0.78 & 0.26 & - & 0.81 & 1.08 & 1.13 \\
\hline
\end{tabular}




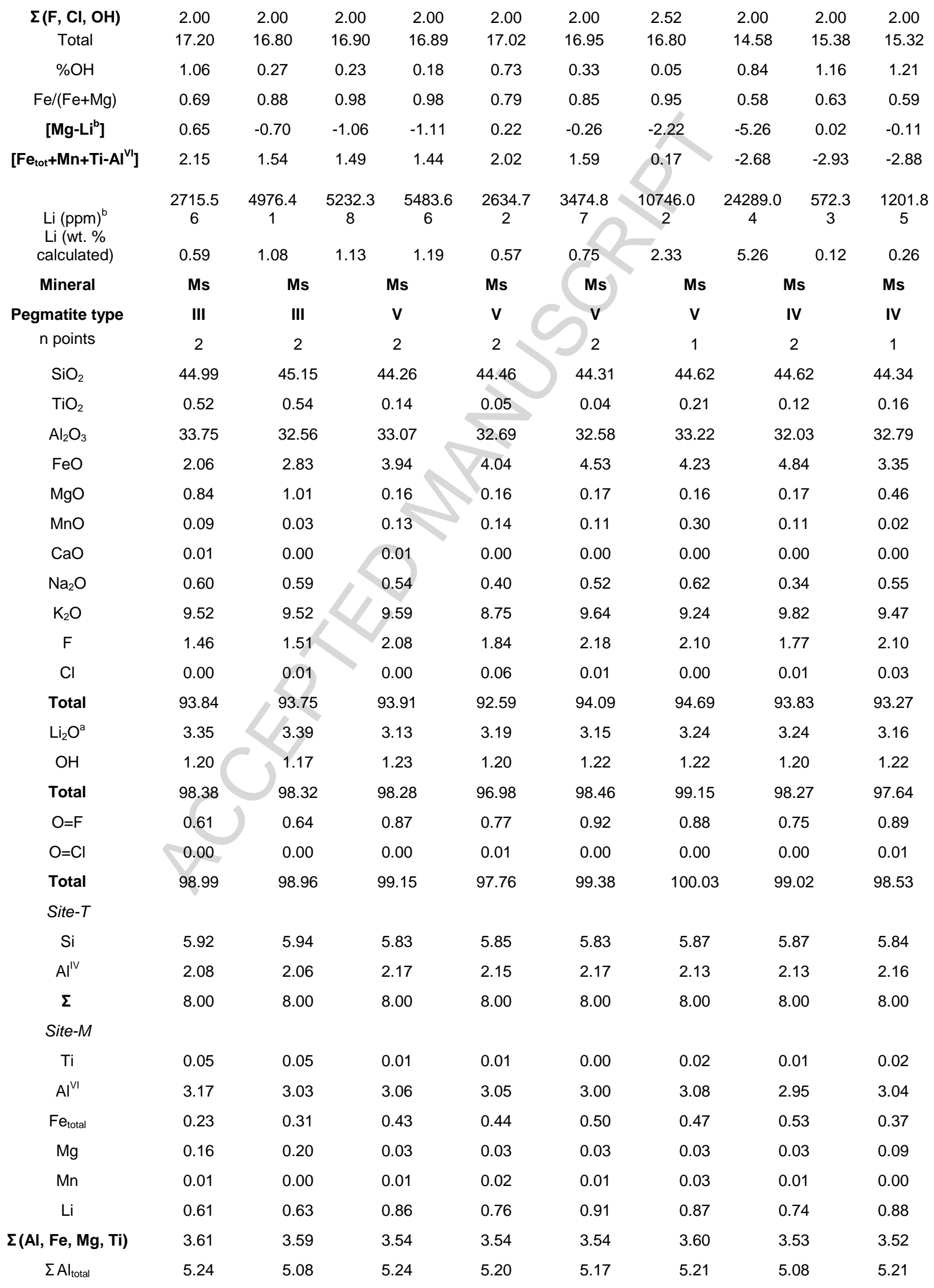




\begin{tabular}{|c|c|c|c|c|c|c|c|c|}
\hline \multicolumn{9}{|l|}{ Site- $A$} \\
\hline $\mathrm{Ca}$ & 0.00 & 0.00 & 0.00 & 0.00 & 0.00 & 0.00 & 0.00 & 0.00 \\
\hline $\mathrm{Na}$ & 0.15 & 0.15 & 0.14 & 0.10 & 0.13 & 0.16 & 0.09 & 0.14 \\
\hline $\mathrm{K}$ & 1.60 & 1.60 & 1.61 & 1.47 & 1.62 & 1.55 & 1.65 & 1.59 \\
\hline$\Sigma(\mathrm{Ca}, \mathrm{Na}, \mathrm{K})$ & 1.75 & 1.75 & 1.75 & 1.57 & 1.75 & 1.71 & 1.73 & 1.73 \\
\hline \multicolumn{9}{|l|}{ Site-OH } \\
\hline $\mathrm{F}$ & 0.00 & 0.00 & 0.00 & 0.01 & 0.00 & 0.00 & 0.00 & 0.01 \\
\hline $\mathrm{Cl}$ & 0.89 & 0.90 & 0.83 & 0.84 & 0.83 & 0.86 & 0.86 & 0.84 \\
\hline $\mathrm{OH}$ & 1.11 & 1.10 & 1.17 & 1.14 & 1.16 & 1.14 & 1.14 & 1.16 \\
\hline$\Sigma(\mathrm{F}, \mathrm{Cl}, \mathrm{OH})$ & 2.00 & 2.00 & 2.00 & 2.00 & 2.00 & 2.00 & 2.00 & 2.00 \\
\hline Total & 15.36 & 15.34 & 15.29 & 15.11 & 15.29 & 15.31 & 15.26 & 15.25 \\
\hline$\% \mathrm{OH}$ & 1.20 & 1.17 & 1.23 & 1.20 & 1.22 & 1.22 & 1.20 & 1.22 \\
\hline $\mathrm{Fe} /(\mathrm{Fe}+\mathrm{Mg})$ & 0.58 & 0.61 & 0.93 & 0.93 & 0.94 & 0.94 & 0.94 & 0.80 \\
\hline$\left[\mathrm{Mg}-\mathrm{Li}^{\mathrm{b}}\right]$ & -0.02 & 0.01 & -0.17 & -0.10 & -0.41 & -0.49 & -0.76 & -0.36 \\
\hline$\left[\right.$ Fetot+Mn+Ti-Al $\left.{ }^{\mathrm{vl}}\right]$ & -2.88 & -2.66 & -2.60 & -2.59 & -2.49 & -2.56 & -2.39 & -2.65 \\
\hline $\mathrm{Li}(\mathrm{ppm})^{\mathrm{b}}$ & 849.09 & 849.09 & 920.59 & 587.52 & 2031.73 & 2397.09 & 3666.74 & 2087.76 \\
\hline Li (wt. \% calculated) & 0.18 & 0.18 & 0.20 & 0.13 & 0.44 & 0.52 & 0.79 & 0.45 \\
\hline
\end{tabular}


Table 2

\begin{tabular}{|c|c|c|c|c|c|c|c|c|c|c|c|}
\hline $\begin{array}{l}\text { Sam } \\
\text { ple } \\
\text { Min }\end{array}$ & $\begin{array}{c}\text { AN\#1 } \\
301\end{array}$ & $\begin{array}{c}\text { AN\#1 } \\
302\end{array}$ & $\begin{array}{c}\text { AN\#1 } \\
301\end{array}$ & $\begin{array}{c}\text { MA\#1 } \\
301\end{array}$ & $\begin{array}{c}\text { MA\#1 } \\
301\end{array}$ & $\begin{array}{c}\text { MA2\# } \\
1301\end{array}$ & $\begin{array}{c}\text { MA2\# } \\
1301\end{array}$ & $\begin{array}{c}\text { MA2\# } \\
1302\end{array}$ & $\begin{array}{c}\text { MA2\# } \\
1302\end{array}$ & $\begin{array}{c}\mathrm{MB} \# 13 \\
01\end{array}$ & $\begin{array}{c}\text { MB\#1 } \\
302\end{array}$ \\
\hline $\begin{array}{l}\text { eral } \\
\text { Typ }\end{array}$ & Ms & Ms & Bt & Ms & $\mathrm{Bt}$ & Ms & $\mathrm{Bt}$ & & Ms & $\mathrm{Bt}$ & $\mathrm{Bt}$ \\
\hline $\mathrm{e}$ & III & III & III & IV & IV & III & III & III & III & IV & IV \\
\hline $\mathrm{Ba}$ & 72 & 12 & 71 & 24 & 13 & 4 & 10 & 79 & 55 & 3 & 3 \\
\hline $\mathrm{Be}$ & 19 & 22 & 7 & 23 & 12 & 26 & 15 & 6 & 18 & 22 & 10 \\
\hline Cs & $\begin{array}{c}71 \\
7960\end{array}$ & $\begin{array}{c}100 \\
7675\end{array}$ & $\begin{array}{c}612 \\
6112\end{array}$ & 51 & 1390 & 28 & 910 & 170 & 25 & 259 & $\begin{array}{c}280 \\
6756\end{array}$ \\
\hline K & 0 & 0 & 5 & 74770 & 68570 & 83150 & 72550 & 66220 & 75400 & 65460 & 0 \\
\hline $\mathrm{Li}$ & 935 & 1040 & 2320 & 1350 & 4475 & 1590 & 5400 & 3200 & 1050 & 4870 & 5200 \\
\hline $\mathrm{Na}$ & 6370 & 4915 & 1820 & 4900 & 1500 & 5000 & 1380 & 1300 & 5240 & 1630 & 1930 \\
\hline $\mathrm{Nb}$ & 110 & 161 & $\begin{array}{c}215 \\
<\end{array}$ & 120 & 396 & 100 & 400 & 220 & 103 & 610 & 610 \\
\hline $\mathrm{PO}_{4}$ & 580 & 667 & b.d.I & 384 & 770 & $<$ b.d.l & $<$ b.d.l & 160 & 340 & < b.d.l & 185 \\
\hline $\mathrm{Rb}$ & 1570 & 1977 & 2660 & 1555 & 4200 & 2230 & 3650 & 2210 & 1240 & 4300 & 4480 \\
\hline Sn & 152 & 230 & 26 & 158 & 20 & 220 & 7 & 4 & 100 & 27 & 35 \\
\hline $\mathrm{Sr}$ & 4 & 2 & 3 & 2 & 1 & 1 & 1 & 1 & 3 & 0 & 0 \\
\hline $\mathrm{Ta}$ & 18 & 27 & $\begin{array}{c}50 \\
1000\end{array}$ & 16 & 95 & 20 & 65 & 38 & 15 & 86 & 90 \\
\hline $\mathrm{Ti}$ & 2630 & 1810 & 0 & 2550 & 10550 & 1650 & 10600 & 15000 & 2140 & 4050 & 4280 \\
\hline $\mathrm{Zn}$ & 134 & 157 & 1050 & 200 & 1494 & 230 & 1600 & 1350 & 123 & 2340 & 2210 \\
\hline $\begin{array}{l}\mathrm{K} / \mathrm{Rb} \\
\mathrm{Nb} / \mathrm{T}\end{array}$ & 51 & 39 & 23 & & 16 & 35 & 20 & 30 & 60 & 15 & 15 \\
\hline$a$ & 6 & 6 & 4 & 0 & 4 & 8 & 6 & 6 & 7 & 7 & 7 \\
\hline
\end{tabular}

\begin{tabular}{|c|c|c|c|c|c|c|c|c|c|c|}
\hline $\begin{array}{l}\text { Sam } \\
\text { ple }\end{array}$ & $\begin{array}{c}\text { MB\#1 } \\
302\end{array}$ & $\begin{array}{c}\text { MB\#1 } \\
303\end{array}$ & $\begin{array}{c}\text { MB\#1 } \\
303\end{array}$ & $\begin{array}{c}\text { PB2\# } \\
1301\end{array}$ & $\begin{array}{c}\text { PB2\# } \\
1301\end{array}$ & $\begin{array}{c}\text { PB\#13 } \\
01\end{array}$ & $\begin{array}{c}\mathrm{VH} \# 13 \\
02\end{array}$ & $\begin{array}{c}\text { CB\#13 } \\
01\end{array}$ & $\begin{array}{c}\text { CB\#13 } \\
02\end{array}$ & $\begin{array}{c}\text { CHED\# } \\
1302\end{array}$ \\
\hline $\begin{array}{l}\text { eral } \\
\text { Typ }\end{array}$ & Ms & $B t$ & Ms & Ms & Bt & Ms & Ms & Ms & Ms & Lep \\
\hline e & IV & IV & IV & II & II & II & V & V & V & VI \\
\hline $\mathrm{Ba}$ & 4 & 40 & 43 & 47 & 27 & 11 & 3 & 6 & 3 & 8 \\
\hline $\mathrm{Be}$ & 22 & 10 & 28 & 13 & 7 & 17 & 22 & 29 & 20 & 64 \\
\hline Cs & $\begin{array}{c}100 \\
7574\end{array}$ & $\begin{array}{l}1210 \\
7920\end{array}$ & $\begin{array}{c}64 \\
7430\end{array}$ & 25 & 120 & 28 & 305 & 138 & 130 & 600 \\
\hline K & 0 & 0 & 0 & 78000 & 60500 & 80400 & 75200 & 79400 & 78500 & 46400 \\
\hline $\mathrm{Li}$ & 2000 & 5470 & 1550 & 630 & 2100 & 725 & 2130 & 1970 & 2800 & 13500 \\
\hline $\mathrm{Na}$ & 4500 & 2110 & 4770 & 5800 & 1500 & 6180 & 3550 & 4970 & 3800 & 6190 \\
\hline $\mathrm{Nb}$ & $\begin{array}{c}190 \\
<\end{array}$ & $\begin{array}{c}375 \\
<\end{array}$ & 130 & 120 & 252 & 140 & 200 & 195 & 150 & 100 \\
\hline $\mathrm{PO}_{4}$ & b.d.I & b.d.I & 30 & 242 & 175 & 440 & $<$ b.d.l & 425 & < b.d.l & 6316 \\
\hline $\mathrm{Rb}$ & 2520 & 5320 & 1800 & 1150 & 1800 & 1580 & 4100 & 2350 & 2420 & 4500 \\
\hline Sn & 185 & 55 & 245 & 90 & 27 & 140 & 540 & 270 & 230 & 150 \\
\hline $\mathrm{Sr}$ & 1 & 1 & 2 & 3 & 3 & 1 & 0 & 1 & 1 & 22 \\
\hline
\end{tabular}




$\begin{array}{ccccccccccc}\mathrm{Ta} & 30 & 86 & 20 & 12 & 30 & 10 & 24 & 37 & 24 & 122 \\ \mathrm{Ti} & 925 & 0 & 2660 & 2850 & 12000 & 1680 & 406 & 1310 & 1050 & 56 \\ \mathrm{Zn} & 460 & 1820 & 190 & 100 & 1230 & 170 & 620 & 320 & 340 & 64 \\ \mathrm{~K} / \mathrm{Rb} & 30 & 15 & 42 & 70 & 33 & 51 & 18 & 34 & 32 & 10 \\ \mathrm{Nb} / \mathrm{T} & 6 & 4 & 7 & 10 & 8 & 14 & 8 & 5 & 6 & 1 \\ \mathrm{a} & 6 & 4 & & & & & & & \end{array}$

b.d.I. Below Detection Limit 
Table 3

Pegmatit Typ

e e

$\mathrm{PB} 2$$$
\text { PB }
$$

\begin{tabular}{|c|c|c|c|c|c|c|c|c|}
\hline PB & II & PB\#1301 & PEG03 & Ms & $\begin{array}{l}\text { Inter } \\
\text { m } \\
\text { inter }\end{array}$ & 725 & -3.6 & 1 \\
\hline AN & III & AN\#1301 & PEG04 & Ms & $\mathrm{m}$ & 935 & -1.5 & 2 \\
\hline AN & III & AN\#1302 & PEG05 & Ms & int & 1040 & -1.3 & 1 \\
\hline AN & III & AN\#1301 & PEG06 & $\mathrm{Bt}$ & $\underset{\text { inter }}{\mathrm{m}}$ & 2320 & 0.5 & 1 \\
\hline MA2 & III & MA2\#1301 & PEG07 & Ms & $\begin{array}{c}\mathrm{m} \\
\text { inter }\end{array}$ & 1600 & -1 & 1 \\
\hline MA2 & III & MA2\#1301 & PEG08 & $\mathrm{Bt}$ & $\mathrm{m}$ & 5420 & 1.6 & 1 \\
\hline MA2 & III & MA2\#1302 & PEG09 & $\mathrm{Bt}$ & int & 3210 & -0.6 & 1 \\
\hline MA2 & III & MA2\#1302 & PEG10 & Ms & int & 1050 & -1.3 & 1 \\
\hline MA & IV & MA\#1301 & PEG11 & Ms & m & 1350 & 0 & 1 \\
\hline MA & IV & MA\#1301 & & $\mathrm{Bt}$ & inter & 4475 & 0.2 & 1 \\
\hline MB & IV & MB\#1301 & PEG13 & $\mathrm{Bt}$ & $\mathrm{m}$ & 4870 & -0.2 & 1 \\
\hline MB & IV & MB\#1302 & PEG14 & $\mathrm{Bt}$ & int & 5200 & 0.8 & 1 \\
\hline MB & IV & MB\#1302 & PEG15 & Ms & int & 2000 & -1.3 & 2 \\
\hline MB & IV & MB\#1303 & PEG16 & $\mathrm{Bt}$ & int & 5470 & -1.3 & 1 \\
\hline MB & IV & MB\#1303 & PEG17 & Ms & int & 1550 & -1.8 & 1 \\
\hline VH & V & VH\#1302 & PEG18 & Ms & $\begin{array}{l}\text { int } \\
\text { inter }\end{array}$ & 2130 & 1.7 & 1 \\
\hline CB & V & CB\#1301 & PEG19 & Ms & $\mathrm{m}$ & 1970 & -1.7 & 1 \\
\hline CB & V & $\begin{array}{c}\text { CB\#1302 } \\
\text { CHED\#130 }\end{array}$ & PEG20 & Ms & int & 2800 & 3.4 & 1 \\
\hline CHED & VI & 2 & PEG21 & Lpd & int & 13500 & -2 & 2 \\
\hline Granite & & SSGC\#13 & GRA01 & $\mathrm{Bt}$ & & 2050 & -1.5 & 1 \\
\hline
\end{tabular}

${ }^{a}$ interm for intermediate unit; int for internal unit

${ }^{b} \mathrm{Li}$ - content of each aliquot obtained by ICP- AES, at BRGM, LAB/ISO Unit (Orléans, France)

${ }^{\mathrm{C}}$ number of measures 


\section{Highlights}

- $\mathrm{Li}$ isotope ratios were measured in white and dark mica at pegmatite field scale

- $\delta^{7} \mathrm{Li}(\%)$ are interpreted with rare-element content from each sample and compared to literature data

- A possible inheritance of isotopic compositions from a common crustal source to granite- and pegmatite-forming melts is suggested.

- The role of $\delta^{7} \mathrm{Li}(\%)$ as isotopic tracer of LCT-type deposits is discussed. 